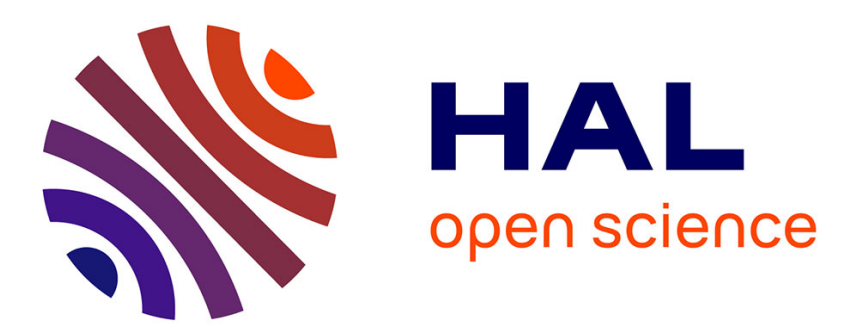

\title{
What We Talk about When We Talk about Poverty: Culture and Welfare State Development in Britain, Denmark and France
}

Tom Chevalier, Cathie Jo Martin

\section{- To cite this version:}

Tom Chevalier, Cathie Jo Martin. What We Talk about When We Talk about Poverty: Culture and Welfare State Development in Britain, Denmark and France. British Journal of Political Science, 2022, 52 (2), pp.805-828. 10.1017/S0007123421000016 . hal-03431608

\author{
HAL Id: hal-03431608 \\ https://hal.science/hal-03431608
}

Submitted on 17 Dec 2021

HAL is a multi-disciplinary open access archive for the deposit and dissemination of scientific research documents, whether they are published or not. The documents may come from teaching and research institutions in France or abroad, or from public or private research centers.
L'archive ouverte pluridisciplinaire HAL, est destinée au dépôt et à la diffusion de documents scientifiques de niveau recherche, publiés ou non, émanant des établissements d'enseignement et de recherche français ou étrangers, des laboratoires publics ou privés. 


\title{
WHAT WE TALK ABOUT WHEN WE TALK ABOUT POVERTY
}

\section{Culture and Welfare State Development in Britain, Denmark and France}

\author{
Cathie Jo Martin and Tom Chevalier
}

Accepted for publication in the British Journal of Political Science

Published online on 23 June 2021:

https://www.cambridge.org/core/journals/british-journal-of-political-science/article/what-we-talk-about-

when-we-talk-about-poverty-culture-and-welfare-state-development-in-britain-denmark-and-

france/165A3CE5CD3B7B0B6985470798CF7C3B 


\section{INTRODUCTION}

Modern welfare state regimes have deep historical roots and early social interventions anticipated later policies of post-war welfare states (Esping-Andersen 1990; Castles 1993; Estevez-Abe et.al. 2001; Flora and Heidenheimer 1981; Huber and Stephens 2001; Petersen et. al. 2010). Long before the twentieth century, Denmark had many hallmarks of Social Democratic welfare states: citizen rights to social support, municipal responsibility for providing jobs to all, and early social investments in mass education. Pre-twentieth-century British policy anticipated the profile of Liberal welfare regimes: no municipal jobs programs, no social rights, late mass education, and passive, punitive poor supports (King 1995; Weir et al. 1988). France, to become a Christian Democratic welfare regime, fittingly relied largely on the Catholic Church and Christian charity for poor supports until the late nineteenth-century, lacked social rights and enacted mass education quite late (Kahl 2005). This diversity of anti-poverty interventions presents a puzzle: Why did historical anti-poverty programs in Britain, Denmark and France differed so dramatically in their goals, beneficiaries and agents for solving poverty?

We suggest that countries historically combatted poverty in such diverse fashion due to fundamentally different cultural views of poverty and the working classes. Where Danish elites articulated social investments in peasants and workers as part of the solution for augmenting economic growth, political stability and societal strength; Britain ones viewed the lower classes as a challenge to these goals. French perceived the poor as an opportunity for Christian charity.

Our paper explores diverse views of poverty and develops a theoretical model of cultural work. Cultural actors and artifacts contribute to the context of historical development of welfare regimes by offering a cultural lens through which other actors evaluate the problems of poverty, their own interests and potential modes of political engagement. Cultural work happens through 
the structure of national cultural tropes and the agency of cultural actors. At a structural level, each country has a distinctive "cultural constraint," or a set of cultural tropes (symbols, labels, narratives and repertoires of evaluation), that appears in the national-level aggregation of cultural products (such as literature), persists through successive epochs, and helps denizens of the country to make sense of the world. Influences on the cultural symbols and narratives comprising the cultural constraint derive from "real" life experiences of authors and their creative renderings of reality. Yet authors also inherit symbols and narratives from the past: cultural tropes found in national corpora of fiction are passed down from one generation of cultural actors to the next and provide continuity of tropes over successive epochs. At the agency level, cultural actors apply cultural tropes to specific policy-making episodes. Cultural actors specialize in putting neglected issues on the public agenda, ascribing meaning to social problems, and popularizing and legitimizing policy positions.

We use two methods to evaluate cultural work. First, we develop an empiricallyquantifiable method of testing cross-national distinctions in historical, literary depictions of poverty. We build corpora of national literature from 1700 to 1920 (including 562 British, 521 Danish and 498 French major fictional works) and construct snippets of text around poverty words. Using quantitative text analyses, we calculate the frequency of words within the snippets associated with the goals (charity versus skills), beneficiaries (individual versus society) and agents (church versus government) of welfare state policies. Second, we use process-tracing in case studies to observe cultural actors' engagement in major episodes of welfare reform.

Our quantitative findings confirm that clear cross-national cultural differences exist in depictions of poverty in eighteenth, nineteenth and early twentieth-century literature in Britain, Denmark and France. Cultural depictions of poverty relevant to the goals, agents and 
beneficiaries of social interventions correspond to the values of each country's modern welfare regimes; therefore, we may reject the null hypothesis that cultural differences do not matter to policy outcomes. Our case studies show that writers self-consciously engage as political actors by employing their cultural depictions in crucial episodes of welfare state development and, particularly in Denmark, that authors' political allies give writers credit for their contributions to political processes. We do not assert that that cultural influences are more important than patterns of social cleavage and the demands of class actors, variations in religious sects, or institutional rules for political engagement. Yet if cultural work provides context for the expression of class interests, culture serves as an intervening variable that helps other actors to imagine their policy preferences and to win the ideological war in policy battles.

We contribute to political science in offering a model and method for evaluating crossnational, historical differences in cultural constructions of policy problems. Unexplained political phenomena are often attributed to cultural differences; yet apart from (contemporary) public opinion research, tools for assessing empirically-falsifiable, historical, cross-national, cultural distinctions are limited. Our work improves on tautological, national cultural explanations of the past (Huntington 1996) in providing an independent measure of culture that is not derived from the institutional differences that cultural arguments are purported to explain.

We add to welfare state theory by refining how a cultural lens adds context to compelling explorations of the impacts of religion, class struggle and political institutional rules in the development of early anti-poverty programs. As neglected actors in stories of policy evolution, authors and their cultural depictions of poverty help to frame early efforts at poor support that establish path dependencies for modern welfare states before the advent of parties, unions, employers' associations and other agents in social policy development. 


\section{CLASSIFYING WELFARE STATE REGIMES}

To understand the relationship between cultural depictions of poverty and welfare states, we must explicate cross-national variations in the institutional design of social programs to combat poverty. Esping-Andersen (1990) identifies three "welfare regimes": Social Democratic

(e.g. Denmark), Christian Democratic (e.g. France), and Liberal (e.g. Britain). Each regime has distinctive goals for poverty reduction, primary beneficiaries of social supports and agents responsible for administering programs.

In terms of goals, policymakers in all regimes develop social interventions to protect individuals from the social risk of poverty. Liberal regimes rescue individuals from poverty with a minimum level of poor support and encourage private charitable activity for needy individuals (Weir et al, 1988; King 1995; Esping-Andersen 1990). Likewise, Christian Democratic regimes also focus on the individual. However, while Liberal regimes focus on the individual considered as poor and in need of support, Christian Democratic view the individual as a worker, with an income to secure (Esping-Andersen 1990; Palier 2010). Yet Social Democratic regimes also embrace social investments, or policies to increase the skills and productivity of citizens so that they may better contribute to broad social and economic goals (Morel et al. 2012). Thus in addition to rescuing individuals from destitution, policy makers use social programs to foster growth-enhancing investments in skills (Iversen and Stephens 2008; Martin and Swank 2012) and they use redistribution to achieve equality in the post-war period (Korpi and Palme 1998; Huber and Stephens 2001).

These welfare state goals are associated with the different beneficiaries of social programs: schemes may be for specific individuals or (means-tested) groups or for a universal population in the entire society. Liberal and Christian Democratic welfare programs create 
benefits for specific individual groups (e.g. elderly, children, the middle-class or the poor). Social Democratic welfare states more likely offer universal programs based on citizenship and social investment policies to help all contribute their work effort to society (Bonoli 1997; Gough at al, 1997; Chevalier 2016). The goal of creating social provisions to strengthen society is very different from either a governmental responsibility to rescue citizens from poverty, granting social rights to the poor, or a view of charity as a social behavior; these instances all retain the primary focus on the needs and rights of the individual. Building up a strong society requires that every individual has necessary skills and citizenship qualities to make an economic and social contribution (Estevez-Abe et.al.2001; Petersen et. al 2010; Martin 2018; Wiborg 2000, 236).

Diverse welfare state regimes rely on different agents and tools to administer social programs. In Liberal and Social Democratic regimes, governments (at the national or local level) provide a social protection funded by taxes: Liberal governments often fund means-tested social policies while Social Democratic governments implement pubic services. Christian Democratic countries make greater use of social insurance programs administered by non-governmental organizations (unions and/or the Church) and funded by workers' and employers' contributions (Esping-Andersen 1990; Huber and Stephens 2001; Castel 1995; Bonoli and Palier 2007).

To explain such diversity, scholars analyze the origins of the development of welfare states with explorations of economic, political, institutional and religious factors. Its economic origins have to do with industrialization, because capitalist production produces greater social risks (Rimlinger 1971; Wilensky 1975). The political origins have been analyzed within the "power resources" approach, exploring the role of trade unions and left parties (Korpi 1974; Esping-Andersen 1990; Huber and Stephens 2001). The institutional origins relate to electoral institutions and associated political coordination (Flora and Heidenheimer 1981, 47; McDonagh 
2015; Martin and Swank 2012; Cusack et. al. 2007). Lastly, studies stress religious influences on welfare development, such as church/state struggles over state-building, the crucial role of Christian-Democratic parties in Continental welfare states and doctrinal differences in religious sects (Lipset and Rokkan 1967; Van Kersbergen and Manow 2009; Kahl 2005).

These works largely focus on the golden age of welfare states after the Second World War, with some attention to the late nineteenth-century. Yet important cross-national divergence in treatments of poverty date back to at least the eighteenth-century. Granted, policy ideas about social protection changed over time. Enlightenment ideas about poverty and the need for labor mobility encouraged outdoor relief for workers; workhouses became more popular with the rise of economic liberalism in the mid-nineteenth century; and structural risks associated with globalization prompted less punitive social insurance protections at the turn of the twentiethcentury (Quadagno 1988). Yet already by 1802, Denmark mandated local governments to provide jobs for all citizens and linked poor support to social investment in mass education; all citizens were granted rights to social supports in 1849 (Petersen et. al 2010, 15). Britain offered only limited relief (largely to deserving poor), did not charge municipalities with providing jobs, did not connect poor relief to skills development and had no social rights during this period. France largely left poverty under Catholic Church control until the late nineteenth-century, offered only passive benefits, emphasized charity and neglected skills (Manow and Palier 2009). Table One reports early distinctions among poverty regimes.

\section{-- TABLE ONE ABOUT HERE --}

Our study investigates how culture intersects with cross-national distinctions in welfare regimes, following work of others studying culture. Petersen et. al. $(2010,39)$ view the formation of collective identities as central to Danish welfare state development. Cox (1992) draws 
attention to deep cultural logics that inform alternative systems of social delivery (See also Castles 1993; Svallfors 1997). Conceptions of the good society differ across Social Democratic, Christian Democratic and Liberal Welfare Regimes (Oorschot, Opielka, and Pfau-Effinger 2008). Ideas and values shape the policy foundations of comparative political economies (Hall 1993; Schmidt 2008). We contribute by offering greater specification of the mechanisms by which cultural artifacts resonate with political reforms.

\section{A MODEL OF CULTURAL WORK}

We suggest that cultural actors and artifacts contribute to the historical development of welfare regimes by offering a cultural lens through which other actors evaluate the problems of poverty, their own interests and possible modes of political engagement. Changes in socioeconomic circumstance, class power and dominant political philosophies periodically prompt countries to adopt new social policies. Cultural values influence the interpretation of new policy ideas and social groups' preferences for specific policy tools. Cultural work happens through the structure of national cultural tropes and the agency of cultural actors.

\section{The structure of national culture: "the cultural constraint"}

At a structural level, each country has a distinctive "cultural constraint," comprised of the national-level aggregation of cultural symbols and narratives appearing in cultural products such as literature. The cultural constraint is predicated on the idea that political and social actors draw from a country-specific "cultural toolkit" to formulate strategies and to ascribe meaning to social problems. (Swidler 1986, 273-6; McNamara 2015). Symbols and narratives include "repertoires of evaluation" or cultural constructs that mold our assessments of the collective good and suggest 
symbolic boundaries among social groups (Lamont and Thévenot 2000). The toolkit is heterogeneous and does not predict specific choices; yet cultural tools and "repertoires of evaluation" are unevenly distributed across nations. Some countries are more likely to access certain cultural tropes than others (Lamont and Thevenot, 2000, 5-6; Berezin 2009). This national-level aggregation of cultural products persists through successive epochs, is used by cultural actors to depict social and political phenomena, and helps citizens to interpret their world. We investigate the cultural constraint in literature (a rich source of symbols and narratives), but the cultural constraint also appears in other cultural forms.

Influences on the cultural symbols and narratives comprising the cultural constraint derive from three sources: "real" life experiences of authors, their creative renderings of reality, and inherited symbols and narratives from the past. First, authors write about life as they know it and their depictions reflect the core values of their societies, assumptions about political engagement, patterns of class conflict, religious beliefs and norms of political institutions. Dickens' portraitures most certainly describe his childhood in the London slums. Yet cultural expectations and institutional rules, class relations etc. may coevolve and have a mutuallyreinforcing relationship, as Macfarlane (1973) shows in his study of British individualism dating back to the thirteenth-century. The practice of English nationals living in nuclear families (unlike in continental Europe) reinforced norms of individualism and individualistic norms reinforced nuclear family living. That cultural assumptions are deeply interwoven with institutional and class arrangements makes it difficult to assign causal weight to culture in historical development.

Yet, second, cultural sociologists are quick to point out that cultural actors do not simply reflect national values and reproduce perfect images of life. Authors' own creative renderings of reality may realign perceptions; in particular, great artists with unique voices may create new 
interpretations (Schwarz 1983). Thus Dickens chooses to emphasize certain themes, such as the mistreatment of children, in his depictions of Victorian poverty.

Third, writers are also influenced in their contemporary depictions of social issues by cultural touchstones they inherit from the past. Symbols and narratives found in national corpora of fiction are passed down from one generation of cultural actors to the next. Fiction writers act collectively as purveyors of the cultural symbols and narratives of their national literary traditions, and they and they conjure up symbols from the past to bear upon present problems (Williams 1958; Poovey 1995; Guy 1996, 71; Milner 2005). Certainly some novels challenge the master narratives of their literary traditions and cultural constructs and cannons evolve over time (Poovey 1995, 7). Yet even as each generation redraws cultural touchstones, one finds continuity in tropes over successive epochs. Familiar touchstones inform the "political unconscious," (or gap between authors' intended goals and their subtext messages) that is unacknowledged by the text (Jameson 1981). Kipling recognizes the power of the national corpus when he writes: "The magic of Literature lies in the words, and not in any man. Witness, a thousand excellent, strenuous words can leave us quite cold or put us to sleep, whereas a bare half-hundred words breathed upon by some man in his agony, or in his exaltation, or in his idleness, ten generations ago, can still lead whole nations into and out of captivity” (Kipling 1928, 6).

\section{The Agency of Cultural Actors: the Dynamics of Cultural Work}

Cultural artifacts must be marshalled to have relevance for historical welfare state development. Therefore, we also observe the agency of cultural actors in policymaking episodes at critical junctures of welfare state development, as authors use cultural artifacts in historically- 
contingent ways to support new political agendas (Berezin 2009). Cultural actors' contribution to public policy is shaped by their comparative advantage as purveyors of cultural artifacts.

First, fiction writers join other intellectuals as the avant-garde in putting neglected issues on the political agenda. In pre-democratic regimes, literature was a crucial medium for intellectuals to debate issues, to shape public consciousness and to influence rulers (Keen 1999, 33). British social problem novelists used their fiction to address issues such as poverty to which politicians paid scant attention. Novel are a terrific medium for inspiring emotional commitments to social concerns; Uncle Tom's Cabin did not cause the Civil War yet it fanned the outcry against slavery (Guy 1996, 11).

Second, writers engage in framing by ascribing specific meaning to economic, social and political problems and solutions; it is also important to note evidence that policymakers receive and use cultural artifacts to explain problems (Griswold 1987). Narratives have enormous influence on our beliefs and assessments about how the world works; imaginaries shape economic action (Beckert and Bronk 2018, 4). The Victorian novelists helped to define poverty and the suffering of working class children in a culturally-specific way (Poovey 1995; Carney 2017; Childers 2001). Of particular interest to this paper is how authors frame the beneficiaries (individual versus society), goals (charity versus social investments in skills) and agents (church versus state) of interventions to resolve social problems. For example, Matthew Arnold sought mass education to facilitate individual self-development: The "grand aim of education" for the middle class is "largeness of soul and personal dignity"; culture brings to the lower classes “feeling, gentleness, humanity" (Kuhn, 1971, 53).

Third, activist writers may participate in coalitions with political allies to win policy battles: they particularly use cultural touchstones to legitimate and popularize esoteric policy 
ideas among a wider public. In this regard, Herman Bang in Tine (1889) credits, blames and implicitly recognizes the role of the old poets who with patriotic words brought Denmark to the disastrous 1864 war: "It is the poets who have filled us with fresh visions and heralded the new age... it is his visions that have carried us to this day...even if they were only illusions...his is the responsibility" (Bang 48). Within these coalitions, authors use cultural tools to legitimize or to challenge structures of authority, as when bildungsroman convey norms of appropriateness (Apol, 2000). Groups may compete over the formation of national identities and offer diverse national myths to claim legitimate political authority (Poovey 1995, 15; Keen, 1999, 2).

Some writers publicly work with political parties and movements, and even serve in Parliament. Others protect their role of legitimizing specific positions by hiding behind their art to claim political neutrality; this may be one reason why their influence has been relatively understudied by political scientists. Thus even as Matthew Arnold carefully reviewed drafts of his brother-in-law's Education Act of 1870 (establishing British mass education), he avoided explicitly-political public activities. As he wrote to his mother on October 17, 1871, "things in England being what they are, I am glad to work indirectly by literature rather than directly by politics" (Arnold 1900, 7vc7.) Hardy argued for necessary political neutrality in a letter to Robert Pearce Edgcumbe on April 23, 1891: "the pursuit of what people are pleased to call Art so as to win unbiassed attention to it as such, absolutely forbids political action." Coleridge vigorously participated in the Tory, Anglican school-building effort, yet he wrote to Beaumont in December 1811, "I detest writing Politics, even on the right side" (Coleridge, 352.)

We make note of our causal claims. We cannot definitively argue that cultural actors and artifacts have a causal impact on the development of welfare state regimes, i.e. that without writers' depictions, welfare regimes would have developed differently. It may be that writers 
were simply influenced by the societal values and material conditions of their times;

alternatively, it may be that authors were agents of ideational change and played a crucial role in shaping modern welfare states. But in either case, with the quantitative evidence we can verify cross-national differences in cultural depictions of poverty and show that these correspond to cross-national variations in welfare regimes. Thus we can disprove the null hypothesis that culture does not matter to welfare state development. Moreover, following Falleti and Lynch's (2009) model of context in causal processes, we view the cultural constraint as a part of the "context" of policymaking. The cultural constraint does not have an independent causal effect;

but it structures how other factors influence welfare regime development. (See Figure A). This is similar to how public opinion structures the effect of political parties (Busemeyer, Garritzmann and Neimanns 2020). Thus, we suggest an "effects-of-causes" rather than a "causes-of-effects" approach, by stressing the relevance of a factor without claiming that it fully explains the outcome (Mahoney and Goerz 2006).

\section{HYPOTHESES}

We use quantitative evidence (discussed below) to evaluate the predicted correspondence between the underlying values attributed to welfare state regimes and the values found in the literary depictions of poverty. We expect to find that texts referencing poverty should have different associations with the goals (skills versus charity), beneficiaries (society versus individual) and agents (state versus church) of social protection in Denmark (a Social Democratic welfare regime), Britain (a Liberal welfare regime) and France (a Christian Democratic welfare regime). We offer the following hypotheses: 
H.1. References to skills words should be greatest in Denmark, where social investment policies are crucial goals of welfare state provision; references to skills words should be lowest in France, where Christian charity was central to anti-poverty interventions.

H.2. References to charity words should be greater in France, which emphasized Catholic charity, and Britain, which sought relief for deserving poor individuals, than in Denmark.

H.3. References to society words should be greater in Denmark than in Britain and France.

H.4. References to individualism words should be greater in Britain and France than in Denmark.

H.5. References to family words should be greater in Britain and France than in Denmark (which emphasizes society and workers).

H.6. References to government words should be greater in Denmark and Britain than in France. References to government in Britain should be lower than in Denmark, because Liberal welfare states combine government provision with a reliance on benefits obtained through markets.

H.7. References to religious words should be greater in France, which relied historically on church provision of social protections, than in Britain and Denmark.

H.7. Finally, an increase of references to poverty in fiction should anticipate significant political reforms in all countries.

Table Two summarizes the words that we expect to find for each policy dimension of the diverse welfare regimes. 


\section{QUANTITATIVE AND QUALITATIVE METHODS}

We use two methods to substantiate our claims: a quantitative analysis of large corpora of national works of fiction to evaluate our structural arguments about culture and comparative case studies to evaluate the agency of cultural actors in episodes of policy reform. First, our quantitative analysis uses computational linguistic techniques (in Python) to test observable differences in depictions of poverty appearing in corpora of British, Danish and French novels, poems and plays between 1700 and 1920 (after which copyright laws limit access). We choose Britain, Denmark and France to represent a Liberal, Social Democratic and Christian Democratic welfare regime. The list of fictional works in the corpora were compiled from country collections of national literature (e.g. the Archive of Danish Literature) and from online lists of important works and authors from the eighteenth to early twentieth centuries. The Danish corpus includes 521 works; the British, 562 works; and the French, 500 works. Full text files are provided by national archives and HathiTrust. We recognize bias both in the initial publication of works (slanted toward upper-class male authors) and in online lists of important works; however, we avoid adding bias by deferring to expert judgment about the collections. The Danish and French corpora include virtually all works available online; where some choices were made about inclusion in the British corpus, we sampled randomly works from all authors on our lists. Because available full-text files are often not first editions, we alter manually the dates of works to reflect their initial publication. Timing of publication is crucial for establishing the sequential relationship between cultural artifacts and reform moments. 
We expect to find cross-national variations in cultural scripts about poverty that correspond to the characteristics (goals, beneficiaries and agents) of contemporary welfare states. We construct snippets of fifty-word texts around poverty words, stem the corpora and take out stop words. We calculate temporal and cross-national variations in word frequencies referencing goals (charity versus skills), beneficiaries (individuals versus society) and agents (church versus government). A supervised learning model is appropriate because our categories are specified by theory: our object is not to assess how an individual document fits into a corpus, but to assess cross-national and temporal differences among works that are presorted by country, language and time (Hopkins and King 2010; Laver, Benoit and Garry 2003). We calculate difference of proportions tests to evaluate significant differences between countries.

We derive our major concepts (government, church etc.) from theoretical discussion, but we must make choices about specific words included in each concept. We initially generated lists of words for each category by identifying the top 200 words in major novels using the HathiTrust word cloud software and coding these words into appropriate groups. We then added synonyms derived from online dictionary searches. We also looked at the frequency of words found in the corpora and choose words that were most frequently used, as we sought to give all languages an opportunity to perform in each category. But we also carefully avoided words with multiple meanings such as "society," which in English refers to both upper-class "high society (most prevalent usage), and the community of people living in a country with shared customs, laws etc. We instead use the term "social." We used "poverty" and other words connoting poor people; however, we did not use "poor" ("stakkel" in Danish) as it may refer to an impoverished person, a suffering person ("poor you") and an inferior. Political terminology for a concept often changes over time. Thus "bienfaisance" and "charite" may both be translated as "charity"; however, they 
are used during different historical periods. We control for this problem by including relevant terms from all periods under investigation and by including varied spelling of words (e.g. Dannemark and Danmark). We have widely read fiction from this era and make sure to use historically-appropriate words (See online Appendix).

Our second method uses process-tracing in brief case studies to evaluate how authors engage in significant welfare reform episodes in Britain, Denmark and France. We seek evidence that networks of authors put the issue of poverty on the public agenda in decades preceding significant policy acts. We explore how major works framed the problem of poverty in light of the goals, beneficiaries and agents of poverty reduction. We identify how cultural actors became involved with political coalitions for poverty reforms and document authors' influence on policy makers. While we cannot show that authors' activities were the determining factor in social struggles, process tracing allows us to demonstrate that fiction writers played the predicted role as political actors in coalitions for policy change and, in some cases, are credited by their contemporaries for contributing to reforms. We primarily cite authors of major works, who engaged with the political debate. This choice creates a bias against authors with minority voices; but it accurately highlights authors who wielded political power. Less influential authors are included in our quantitative corpora; their voices are thus preserved in the overall cultural profile of literary output.

\section{QUANTITATIVE FINDINGS}

Analyses of the British and Danish corpora using machine learning techniques show significant and largely predicted differences. (See Online Appendix for difference of proportions 
tests.) Figure Two shows Denmark has the highest references to poverty. Some increase in poverty words precedes reform moments in 1800 and 1900 in Denmark, and 1800 and 1860 in France.

Figure Three shows that frequencies of skills words are significantly higher in Denmark than in Britain or France for most periods. In all three countries, skills were more important to poverty at the end of the eighteenth century with enlightenment ideas, declined with the punitive attitudes toward poverty in the mid-nineteenth century, and rose again at the end of the century. See online appendix for means of proportion tests.

Figure Four shows that charity words are significantly more frequent in British and French snippets than in Danish ones (where these are non-existent in some periods.) Britain scores more highly than France in the late eighteenth-century because poverty was so often associated with suffering (often upper-class) women rather than workers.

Figure Five confirms our predictions that the social democratic welfare regime of Denmark has, for most periods, significantly higher frequencies of society words than Britain and France (for some periods). Society references are highest in France and lowest in Britain during the French Revolution.

Figure Six confirms our prediction that individual words are higher in Britain and France than in Denmark. Individualism declines somewhat in Britain in the late nineteenth-century with the move toward perceptions of structural poverty. Figure Seven shows that family words are also significantly higher in Britain and France than in Denmark as predicted.

Figure Eight shows that Denmark has the highest frequency of frequencies of words associated with government, followed by Britain and then France. References to government 
words decline in Denmark at the end of the nineteenth-century with the rise of the non-state cooperative movement and industrial self-regulation.

Figure Nine does not confirm our expectations that religion words would be most frequent in France because the church was historically responsible for social provision. Although France scores more highly than Britain, Denmark has the highest frequencies of religion words. This finding is consistent with the view that the Lutheran church acts as a stand-in for local government in early state development in Denmark (Knudsen 1995); a strong church is consistent with a strong state, unlike in France. Religious words in Denmark are particularly high during the evangelical activism of the mid-nineteenth century and these words drop off everywhere with secularization at the end of the century.

Thus, our findings largely confirm our hypotheses. In Denmark, we found high word frequencies on the "state," "skills," "society" and "religion" dimensions. In Britain, we found medium-high word frequencies on the "state" and high frequencies on "individualism" and "charity" dimensions. In France we found high word frequencies on the "church," "individualism," and "charity" dimensions. While cultural depictions in each country also respond over time to shifting economic climates, class struggle, political institutions and dominant ideas about the public space, the cross-national differences among countries endure.

\section{CASE STUDY FINDINGS}

We now offer process tracing of crucial cases to document authors' involvement with policymaking episodes, focusing particularly on the early nineteenth and early twentieth 
centuries, when countries finally developed social insurance programs. Table Three summarizes historical differences in the development of welfare states in Britain, Denmark and France.

\section{-- TABLE THREE ABOUT HERE --}

\section{Denmark}

In 1700, Denmark was a primitive land with low productivity, serfs, and a low standard of living yet by century's end, enlightenment-inspired reforms transformed Danish society and prevented the French Revolution from having significant impact on Denmark (Christiansen et.al. 2010, 111-15). The Poverty Commission of 1787 (Fattigkommissionen af 1787) charged municipalities with providing work, shelters for the unemployed, hospitals for better health care and homes for the impoverished elderly. Poverty reforms were simultaneous with the creation of a mass education system. The 1802 and 1803 regulations intensified prohibitions against begging, but created a poverty tax to provide resources for the poor (Wessel Hansen 2008, 179). Eighteenth-century advocates for improvements in the life of peasants linked social reforms to the expansion of agricultural productivity, sought social investment in education, and presupposed that the social life of peasants was necessary to the mandates of economic growth (Sundberg 2004, 146).

Authors put poverty, education, and land reforms on the public agenda far in advance of the 1787 commission. In the 1720s, Ludvig Holberg (the "father of Danish literature" and an expert on Nordic mythology) began writing plays in the Danish language, featured peasant characters (a break with the past), and consistently emphasized poverty's negative impact on society, the importance of skills-building and the necessity of state intervention. For Holberg, poverty harmed both individuals and society; therefore, it was in the interests of estate owners to 
improve the lives of their peasants. "Whoever loves himself should act in a benevolent way toward his peasants, as there is a union between their interests. The devastation of the peasant will be the devastation of the estate" (Holberg 1971, 1720_191-216). Holberg's title character in his 1741 adventure novel, Niels Klim 's Journey Under the Ground, complains that his skills are not being sufficiently recognized. He is told that the collective comes first: "Merit ought to be rewarded, but the reward should be adapted to the object, that the State may not suffer" (Holberg 807 of 1846).

Holberg was immensely important to enlightenment reformers and writers alike through his work and by bequeathing his fortune to the Sorø Academy, a school for educating future statesmen. The academy adopted Holberg's ideas (teaching in Danish, encouraging study of the old Nordic myths) and hired his former students such as Jens Schielderup Sneedorff (later tutor to the crown prince), who wrote that peasants should be honored members of society (Plesner 1930, 20-28). Sorø educated estate owners, such as Christian Ditlev and Johan Ludvig Reventlow, who would head the Poverty, Education and School commissions set up in the 1780s. In a letter dated June 19, 1770, Ludvig wrote to his sister Charlotte: "I believe with you that the greatest happiness of the state is to have happy and rich peasants instead of a few wealthy landowners" (Bobe II, 3).

Romantic poets and playwrights at century's end affirmed that a strong society required the participation of all classes of people. Adam Oehlenschläger (most famous poet before 1870) presented his vision of the "organic society" in an 1800 prize-winning essay considering "Would it be beneficial to Scandinavian belles lettres if old Norse mythology were introduced and generally adopted in place of Greek mythology?" (Hanson 1993, 181.) Oehlenschlager's evil title 
character in Hakon Jarl (1805) is contemptuous of society, "as afraid Of his own warriors as he is of' the enemy (93), steals farmers' daughters and prefers to rely on slaves (105).

After the Crown Prince and his close associates (including the Reventlow brothers) staged a bloodless coup in 1784, writers were important allies in the political coalitions to reform the Danish political economy and to provide legitimacy for the new regime. Oehlenschlager and other writers met to discuss crucial issues of the day at the Drejer's Klub and formed the Society for Future Generations (which civil servants also joined) to nurture citizenship and disseminate useful knowledge (Bokkenheuser 1903, 24-5; 177-182). In 1785, Christen Henriksen Pram and Knud Lyne Rahbek (from the Drejer's Klub) started a journal, Minerva that featured articles on art and politics and included among its 496 subscribers 41 members of the extended royal family (Munck 1998, 216). When reactionary estate owners from Jutland opposed the reforms, writers intervened with a war of words to ardently support the new regime and the end of serfdom. Knud Rahbek claimed that writers were as crucial to the late eighteenth-century reforms as civil servants such as Bernstorff, Reventlow and Coljbørn (Bokkenheuser 1903, 116-118).

Denmark entered a period dominated by economic laissez-faire thinking in the middle of the nineteenth-century, for example, abolishing guilds in 1857. The Constitutional Act of 1849 ended outdoor support and denied rights to able-bodied, workhouse inhabitants; yet it simultaneously created social rights to public support for those unable to support themselves (Petersen et. al. 2010, 70-2). No significant anti-poverty legislation was enacted apart from the constitutional reform. Yet despite the ruling liberal ideology, strong societal movements, such as the Danish folk high school movement, sought to sustain high levels of social investments in poor workers to combat poverty at the municipal level and to preserve collective strands in society (Petersen et. al., 2010, 79-80). Authors inspired local communities to engage in self-help 
activities. In 1838, Nikolai Frederik Severin Grundtvig offered poverty as a metaphor for individualism threatening collectivism: "the impoverishment of the individual heart and spirit for those who have forgotten the collectivism of the golden age" (Grundtvig 1904-9, 122-5).

In late nineteenth-century, Denmark encountered competitive world markets, social problems attendant to industrialization, expanding skills requirements and industrial conflict associated with labor market liberalization (Gourevitch 1986). Yet the political realm was deeply dysfunctional due to stalemate between the Right Party (controlling the executive and upper house in parliament) and Left Party (controlling the lower house). When unable to gain parliamentary approval for his finance policies, Prime Minister Jacob Estrup imposed provisional budgets. The Left Party refused to address most measures and virtually no significant legislation occurred from 1875 until the early 1890s (Henrichsen 1911, 67-72). Finally, parties collaborated on comprehensive solutions to social problems and universalism starting with the 1892 Old Age Pension and culminating with the 1907 Unemployment Act (Petersen et. al. 2010, 81-2).

Two interrelated networks of authors worked to advance social and democratic reforms on the public agenda. Led by literary critic Georg Brandes and Edvard Brandes (writer and future finance minister), Modern Breakthrough (or free-thinking) authors attacked the earlier generation's romanticization of working class lives with a new realism that starkly depicted social problems (Skovgaard-Petersen, 1976). Another group of authors (Holger Drachmann, Jakob Knudsen, Henrik Pontoppidan and Johan Skjoldborg) were associated with the folkloric movement and the folk high school movement inspired by Grundtvig (Coe 27).

These authors framed poverty in specific ways that anticipated later social democratic welfare state assumptions. They linked poverty to inadequate social investment in skills, viewed industrialization as an opportunity for growth and emphasized connections between growth and 
social protections (Skovgaard-Petersen, 1976, p. 11-12). They offered favorable portrayals of workers as a class and moved away from the distinction between the deserving and undeserving poor. Thus Nobel-prize winner Henrik Pontoppidan's Lucky Per conveyed appreciation for industrialism, sympathy for workers harmed by industry, a benign view of unions, and education and social protections as the best means for offsetting industrial risk. For Per, "It struck him what a fresh and active sympathy the workmen manifested from the beginning, although most came out of Copenhagen's lower classes...They did not quarrel with anyone and were held together by mutual respect" (Pontoppidan, 480). Per's finance, Jacobe, founded a school that would become "a sanctuary, a refuge...the children will also be given the capital for a bright and fruitful sense of life that they can later draw upon" (477-8).

Authors emphasized that poverty detracted from society and social peace, as is captured in Holger Drachmann's play, “There Once Was," the most performed play in Danish history. The male lead tells his wife that "the little people must bear life's burdens together" (72). The final song, "We love our land," sung every year on the summer solstice, is an ode to the strength of Danish community, love of peace and commitment to defense against external enemies and internal discontent (Drachmann 1902, 121.) Modernists regarded state institutions more favorably than their British counterparts (Skilton 1980, 37-43); while appreciating the importance of private community action, they pointed to the pitfalls of the private system. Thus Jakob Knudsen in The Old Priest wrote about the corruption associated with funding a new private Folk High School and the need for some oversight to protect against violation of the social bonds.

The dysfunctionality of the political realm meant that cultural politics played a pivotal role; writers considered literature to be the best venue for political change (Frederiksen 2020, 65- 
6.) Viktor Pingel, leader of the student society movement and a close associate of Georg Brandes, noted that the struggle for democracy in Denmark was very much along cultural lines (Skovgaard-Petersen 1976, 135). Fiction writers became directly involved as activists in the fight against Estrup in November 1878, by developing their own faction of the Left Party, entitled the "literary Left" (or European Left), to elevate literary perspectives in social debates (Hvidt 2017, 122-8). Edvard wrote to his brother in 1877 that the problem was not simply Right Party strength but Left Party weakness, and advocated for cooperation with the farmer wing of the Left (Sevaldsen, Jørgen. 1974. p.235-8).

Authors worked closely with Left Party politicians, such as Viggo Hørup (who founded Politikken with Edvard Brandes), to sway public opinion on social rights, education and religion (Frederiksen 2020, 70-1, 114, 166-7). The Literary Left also helped the Left Party forge a new ideological platform that was crucial to the battle for constitutional reform. As Left Party leader Christian Berg noted, "As long as the other had all the intelligence, it was a hopeless case to make people understand that the true opinion was on our side." But with the help of the Literary Left, "We waged war with culture more than with the party." The Literary Left constituted, "our poets, our professors, our jurists, journalists...Like manna from heaven, the literary Left came down into this desert...we had what we lacked" (Hvidt 2017, 127-8.) The alliance between the literary and peasant factions disintegrated in 1884 , when peasant wing formed an alliance with the moderates within the Left Party. Yet the faction later became the highly influential Radical Left party that was extremely important to the origins of the welfare state (Henrichsen 1911, 96).

Finally, authors helped to facilitate links between farmers in the Left party and workers in the social democratic party. The evangelical farmers and urban worker had little contact and a strong cultural disconnect. Yet the authors and intellectuals communicated with both groups and 
authors played an important role in facilitating connections in advance of democratic change in 1901. The common ground between workers and farmers, which became one of the hallmarks of the social democratic system, helped to pave the way for the 1907 unemployment insurance act. The act embraced principles of voluntarism and state subsidies for funds. This enabled the continuation of private initiatives coming from unions, rural cooperative self-help movements, and insurance pooling. Thus the 1907 act benefitted both urban and rural workers and strengthened the political coalition at the heart of the social democratic model.

\section{Britain}

In 1800, Britain encountered rising problems of poverty, as the enclosure movement (turning agricultural workers into wage laborers), growing industrialization, and urbanization destabilized society (Doheny, 335). Yet unlike Denmark, Britain produced limited welfare innovation (apart from the small Relief of Poor Law act in 1782) and largely left the 1601 poor law in place until the new Poor Law of 1834. Whereas Denmark expanded municipal responsibility for job provision and social investments, few British municipalities adopted the Speenhamland system or developed public jobs; public poor relief remained limited and punitive and private or church philanthropists added to public programs (Block and Somers 2014, 12734). Thereafter, the new poor law in 1834 reaffirmed the most punitive impulses of the 1601 act, forcing able-bodied poor only to receive support in prison-like workhouses.

The Danish celebration of the peasant found no analogue in Britain. Eighteenth-century novelists largely ignored the working class or treated them humorously. Defoe wrote extensively about religious freedom and individual responsibility, but paid scant attention to poverty or societal concerns (Marshall, 2007, 556, 561). In Robinson Crusoe (1721), the title character lives 
outside of society for a quarter century; commercial capitalism and slave trading allow Robinson to become a wealthy man (28).

At century's end, writers in the conservative (Burke, Trimmer) and Radical (Godwin, Wollstonecraft, Shelley) camps held opposing views of the French Revolution; yet neither side paid much attention to working class poverty. An Essay on the Principle of Population (1797) by Thomas Malthus did much to set perceptions of the poor. Malthus believed that population would increase with a rise in the means of subsistence, unless population growth was limited by checks such as moral restraint (late marriage), vice (prostitution) and misery (starvation) (Malthus 1809, 27-8). Therefore, poor supports would only exacerbate poverty. While critics denounced Malthusian pessimism, there was a strange convergence of left and right on concerns about overpopulation and excessive reproduction among the lower classes. Denmark and Norway had lower population density than Britain in 1800 and the Danish government sought to increase population. Yet Malthus attributed Norway's (then part of Denmark) density to positive policy (later marriage rates) rather than higher mortality; he was impressed that Norwegians (alone in the world) had thought through the problems of surplus labor and were more concerned about the happiness of the working class than elsewhere (Malthus 1809, 326).

Authors who did write about poverty framed it in ways that resonated with the assumptions of the liberal welfare state regime. They linked poverty relief to charity for suffering individuals (usually from the upper and middle classes) rather than for social investments in skills, differentiated between the deserving and undeserving poor and expected private philanthropy to augment state efforts. Gripping stories described gentry forced into declined circumstance and women suffering from profligate male misbehavior, such as Mary Wollstonecraft's (1798) title character in Maria and the Wrongs of Women. Samuel Richardson's 
Pamela concerns a gentleman's family that has fallen into poverty. Pamela's virtuous defense against the untoward advances of her master is offered as exemplary behavior on the part of the poor, as Pamela is "bred to be more ashamed of dishonesty than poverty" (Richardson, Samuel. Pamela. 1740_388-1169, 1179). Pamela transforms her master from monster to husband and inspires a spirit of charity among her new upper-class associates.

Instead of linking poverty to a lack of social investment in education, many British elites feared mass literacy as a threat to social stability (Stone 1969; Brattlinger). Coleridge recognized that some schooling for the poor could limit alcoholism (Coleridge, Samuel Taylor, 1796). Yet Wordsworth was much more pessimistic about educating the poor; in a letter to Francis Wrangham, he rejected a state system of national education and argued that schooling should concentrate on those at top and then filter down (Knight 1907, 180).

Authors viewed poverty as under government jurisdiction, yet private Christian charity should augment public benefits and benefits should be kept low so as not to fan Malthusian tendencies toward overpopulation. Radical Jeremy Bentham conceptualized a National Charity Company funded by a poor tax to give some benefits to the deserving poor and send the undeserving poor to workhouses (Bentham 2010). In 1787, Sarah Trimmer advocated for Houses of Industry for the able-bodied poor, and even sought residential schools where five-year-old girls could learn spinning, etc. The schools would attract young gentlewomen benefactors and eliminate need for government funding (Trimmer 1801, 69-70). Mary Shelley's monster in Frankenstein longs for wife and hearth; yet his creator fears that the monster's progeny would threaten mankind. Malthusian overpopulation became a powerful literary meme even for those such as Charles Dickens who are sympathetic to the working class (Steinlight 2018, 7-8, 22). 
The New Poor Law of 1834, which reduced poor taxes, ended outdoor relief, and expanded prison-like poor houses, was a product of Whigs on the left, such as Lord Brougham. Some Tories such as Wordsworth opposed the law, sensing that curbs on almsgiving would reduce opportunities for Christian charity (e.g. as in the poem "The Old Cumberland Beggar") (Chandler 1980, 756). Yet the surprising feature of the law was how much convergence there was on this punitive approach and how the left led the vanguard against outside poor support.

Late nineteenth-century decline of British industry and rising structural employment amplified attention to working class misery, social strife and skills deficits (Williams 1896, 1). Britain responded with the National Insurance Act of 1911 that created health insurance and a tiny, compulsory unemployment insurance. The pilot unemployment insurance program represented a small break with the past by acknowledging structural unemployment; however, protections were limited, no labor exchanges facilitated employment, and most poor continued to be served through means-tested social assistance (Gough et al, 1997; Foerster 1912, 300-304; (Shepard 1912, 232-4). Thus, the act followed Britain's history of social innovation: support entailed an individual minimum rather than a societal maximum and state power controlled individual malfeasance rather than provided jobs (Harris 1992, 119).

After passage of the 1834 law, Victorian social reform novelists (e.g. Charles Kingsley, Charles Dickens and Elizabeth Gaskell) depicted the punishing lives of the poor with realistic, heart-rending portrayals of individual suffering; yet they stopped short of more systemic views. Victorian writers reinforced political attention to the agonizing conditions of women and children, railed against child labor, celebrated charitable sentiments, and anticipated the pillars of the later liberal welfare state model: the differentiation of classes of the poor and a reliance on charity. Dickens greatly resented Malthusian descriptions of the poor and grieved for poor 
children (Hughes, 1903, 1), yet even he neglected the problem of lack of skills for society. Dickens wrote A Christmas Carol to attack the report of the Second Children's Employment Commission, and bragged about his literary power when he told commission member, Southwood Smith, that his book would have "twenty thousands time the force" of a pamphlet on child labor (Henderson, 2000, 145).

Later writers linked poverty to structural risks associated with capitalism and globalization (Crosthwaite 336-7). Writers and policymakers in the TH Green network were inspired by the earlier social justice novels of Kingsley and Dickens, but also viewed poverty as a systemic problem. The Fabian Society drew socially-concerned fiction and nonfiction writers from the upper and middle classes such as Sidney and Beatrice Webb, George Bernard Shaw, H.G. Wells and Bertrand Russell (Garver 2011, 92-3).

Yet despite growing concerns about structural unemployment, even these authors framed poverty in ways resonating with the liberal welfare regime, drawing distinctions between the deserving and undeserving poor and depicting a culture of poverty. In George Gissing's The Netherworld, most of the poor descend into lives of drunken squalor. Fabian Bernard Shaw (45) poked fun at the culture of poverty in Pygmalion: "Undeserving poverty is my line....it's the only one that has any ginger in it." Yet even Fabians shared Malthusian concerns about overpopulation, cultural degradation and the gene pool. Wells refers to the "extravagant swarm of new births" as the "essential disaster of the nineteenth century" (Carey 1992, 1). In The Time Machine (1898), Wells imagines an out-of-control underworld population that preys on the upper-world inhabitants (Wells1898, Loc 500).

Writers portray poverty in terms of individual self-development for the reformer and rights for the poor. Mary Augusta Ward's eponymous Robert Elsmere (1888) evolves from 
country parson to social activist who has "gone mad" with a new religion: "Dirt, drains, and Darwin” (Ward 3189). Hardy’s biographer, Michael Millgate (2004, 88-9) describes Hardy’s long-term goals as "self-education, self-development and self-discovery" (Millgate 2004, 100). George Gissing’s Denzil Quarrier(1892_262-109) articulated an individual right to social support: "if I found myself penniless in the streets ...It would be the duty of society to provide me with [social support].... as civilized beings we have rights."

Fabians diverged from past anti-poverty measures: the Webbs highlighted structural unemployment and proposed labor exchange and training in the Minority report, yet they retained a major role for private charity (Webb 1909, 199, 208). They met repeatedly with Winston Churchill in advance of the 1911 national insurance act (Webb 1909). Moreover, Gilbert $(1976,1058-60)$ suggests that the limitations of the national act reflected Lloyd George's interest in protecting the City of London from excessive social reforms. Yet even the Fabians reinforced limitations of the liberal welfare state in seeking conditional relief to improve the character of the poor. The act was very British in that the state could only use power to relieve the distress of suffering individuals (Gilbert 1966, 855-61).

\section{France}

The failure of the Protestant Reformation allowed the Catholic Church to remain the primary agent for social protection in France (which had no poor law until the late nineteenthcentury). The Catholic Church provided poor support and charged its flock with a moral duty to provide alms (Geremek 1997; Gutton 1974). In 1724, the French King provided some minimal financing for general hospitals to hold beggars and vagrants, but most of these institutions remained privately run under Church control (Gutton 1974; Castel 1995; Schwartz 1988). Some attempts were made to provide public outdoor relief during the French Revolution (Hudemann- 
Simon 1997, 19-20), yet the social assistance system remained complex, underdeveloped and reliant on religious and private financing (Castel 1995, 374; Dessertine et Faure 1992).

Furthermore, in the wake of the French Revolution, the political regime rather than the welfare regime claimed political attention and poverty was largely left off of the agenda.

Throughout the $18^{\text {th }}$ century, writers depicted the poor as akin to the "noble savage" ("bon sauvage") or deserving innocents with few resources, who are neither lazy nor eager for excessive wealth. In Rousseau's famous novels Julie ou La Nouvelle Héloïse (1761) and Emile ou De l'éducation (1762), relatively poor, rural people claim a moral advantage over the urban rich: "having always lived a uniform and simple life, I have kept in my spirit all the clarity of primitive lights...my poverty was moving away the temptations that dictate the sophisms of vice" (Rousseau. L'Emile 1762_23-29). These positive depictions of the poor reinforced leaving poverty off the political agenda and charitable support for paupers to the Church.

No French best-sellers in the early $19^{\text {th }}$ century centrally addressed poverty (see Lyons 1987 for the list of best-sellers during the $19^{\text {th }}$ century in France). Instead, two groups of widely read authors were important in focusing attention on other issues. First, religious novels and stories were hugely popular: thus La Fontaine's Fables (1668) and Fénélon's Télémaque (1699), although written in the $17^{\text {th }}$ century, continued to command the highest readership by extorting the importance of moral and religious education for the individual. Second, Enlightenment authors (e.g. Voltaire and Rousseau) were widely read in the nineteenth century; yet they discoursed on the political regime (the Revolution's legitimacy and the best political institutions) and neglected poverty as a political issue. Their works addressed "civil" and "political" citizenship rather than "social citizenship," to use Marshall's words. The absence of attention by writers to the poverty issue is met with a lack of public intervention. 
The landscape shifted around 1840-50, when the literary movements of romanticism and realism gave birth to hugely-successful social novels ("romans sociaux"). Eugène Sue's bestselling Les mystères de Paris (1842-1843) dove into the lowest classes of society in Paris and put poverty on the agenda from a qualified socialist perspective. Sue was very engaged politically and was elected in 1850, after the 1848 revolution, as a socialist Republican deputy. During this period, Republicans sought "national workshops" ("ateliers nationaux"), public assistance and a right to work. Yet Conservatives, Liberals, Monarchists and the Church eventually barred state intervention (Renard 1986).

The other very important figure at the time was Victor Hugo. Hugo's famous social novels paid great attention to working class poverty and depict the poor with both positive and negative connotations. Initially, he pictured the Church as the appropriate agent of poor relief and the state as a repressive rather than ameliorating force. Victor Hugh's Quasimodo in Notre Dame de Paris (1831) is an orphan hunchback who deserves relief provided by the Church, i.e. Frollo. Hugo was at the time still a Conservative, and was even elected to Parliament in 1848. Yet, after his initial social novels, Hugo addressed poverty directly with his Discours sur la misère ("Discourse on poverty"), offered to Parliament in 1849. The discourse did not produce reforms and after the coup d'Etat in 1851, Emperor Napoléon III rejected developing public assistance programs. With the birth of the Second Empire, both Eugène Sue and Victor Hugo went into exile, and censorship associated with the regime led to a depoliticization of novels (Lyons 1987).

Social novels remained quite popular, however, especially when the Third Republic replaced the Second Empire after 1870. Victor Hugo, while in exile, remained very influential. His famous Les Misérables (1862) put the poverty at the center of the novel. The expression "les 
misérables" means both the poor and the despicable in French, and Hugo's characters included both the poor and despicable Thénardier, and the poor but noble Jean Valjean. Valjean struggles to help the poor, but is hounded by Javert, policeman and representative of state authority, who represses rather assists unfortunate characters in the novel.

With the fall of Napoléon III and the birth of the Third Republic, anti-clerical Republicans triumphed over clerical Monarchists and finally progressively shifted the balance of political life between church and state (Manow and Palier, 2009). French authors of this period contributed to the Republican cause by stressing the structural nature of poverty under conditions of expanding social protections; yet, they continued to depict state intervention with some skepticism. The most famous author at the time was Emile Zola. Zola was highly politically engaged in favour of the Republic but, unlike Sue and Hugo, he never ran for office. However, through his famous social novels as well as his journalism, he had great influence at the time, shaping the political debate.

Zola's novel Germinal (1885) for instance describes the difficult life of miners in Northern France. Etienne falls into poverty after losing his job, becomes a miner and then leads the workers' strike against the company. Involuntary unemployment associated with economic transformation pushes the able-bodied into poverty and labor activism is appropriate (Sassier 1990). By contributing to put poverty on the agenda, Zola fueled the Republican coalition that eventually led to the "laicization" of social assistance, which occurred with laws passed in 1893 , 1905, and 1913 (Renard 1986, 22). Yet the Church continued to provide benefits parallel to growing public protections against social risks (Renard 1986, Dessertine and Faure 1992). Republicans sought a strong role for the central state; Traditionalists preferred delivery by Church and family; and the fragmented system of social welfare provided by municipalities 
constituted a compromise (Renard 1986). The fragmented public system was reinforced in 1930 but compulsory unemployment insurance implemented only in 1958 (Daniel and Tuchszirer 1999; Hatzfeld 1971). Indeed, despite the demand for social protection, the state was not always positively perceived even by Republicans, as is obvious with Zola's life. In Germinal, the working class must defend itself against the state, which violently represses the strikes (Radé 2015), and Zola was himself forced to leave France due to his engagement in favour of Dreyfus through his article "J'accuse!"

\section{CONCLUSION}

The distinctions among modern welfare regimes have deep historical roots. While similar policy ideas and socioeconomic challenges motivated British, Danish and French policymakers to fight poverty through the ages, early anti-poverty experiments anticipated modern welfare state regimes distinctions in the goals, beneficiaries and agents of social programs. Denmark featured a strong role for social investment in anti-poverty programs as early as the eighteenthcentury, when local governments were charged with providing work to the able-bodied. The British state assumed responsibility for controlling the poor; but interventions remained minimal and punitive. The church largely retained control over poor support in France until the late nineteenth-century and government programs continue to be supplemented by non-state actors. Moral education rather than skills development was a primary object of concern.

We suggest that countries' specific responses were mediated, in part, by the mobilization of cultural actors and artifacts. Cultural actors, acting as avant-garde activists, helped to put new concerns about poverty on the political agenda. Writers framed policy problems and solutions with culturally specific references to the goals, beneficiaries and agents of the welfare state. 
Writers were particularly important to the popularization of, mobilization of support for and legitimation of specific policy solutions to poverty problems. Their political allies credited them with having an impact on welfare state trajectories. Authors were influenced in this framing by their inherited cultural tropes (the cultural constraint) but reworked and updated these touchstones to address changing socioeconomic conditions and hegemonic ideas about poverty reduction. Thus fiction writers grappled with the dialectical tension between sustaining cultural and institutional continuities, even while facilitating change in the cultural narrative.

We use quantitative computational linguistic methods to document significant crossnational differences in the language of poverty within large corpora of British, Danish and French literature dating back to 1700 . Already by the eighteenth-century, Danish writers discuss poverty with references to skills and society; British writers reference charitable interventions for vulnerable individuals (especially women and children). Both countries include high levels of references to government. French authors make few references to government but have high frequencies of words associated with individualism, religion and charity.

These findings have ramifications for the study of welfare states. For example, a deep commitment to building a strong society, rather than redistribution for equality, dates back to the early 1700s in the Danish social democratic state, and this helps us to understand the modern social democratic emphasis on social investment policies. While scholars debate whether challenges associated with globalization and deindustrialization are bringing about a convergence among welfare states, the persistent of nationally-specific themes in depictions of poverty through the eighteenth, nineteenth and early twentieth centuries may indicate some consistency in future policy trajectories (Palier 2010). 
Our work also has implications for the study of culture and politics. Scholars recognize that cultural values are associated with modern cross-national distinctions in welfare programs (Svallfors 1997), yet pinpointing the historical contributions of culture has been more elusive. We fill this gap with our empirical analysis of the cultural constraint within British, Danish and French literature, and document both cultural continuities across time and cultural differences across nations in depictions of poverty. Writers act collectively to rework imaginaries about poverty for new challenges at each age of social innovation. 


\section{BIBLIOGRAPHY}

Apol, Laura (2000) Tamings and Ordeals. The Lion and the Unicorn 24, no. 1: 61-80.

Arbedsløshedkasseloven, 9. april 1907 Danmarkshistorien.dk.

https://danmarkshistorien.dk/leksikon-og-kilder/vis/materiale/arbejdsloeshedskasseloven-1907/.

Arnold, Matthew (1900) Letters of Matthew Arnold: 1848-1888. Collected and Arranged by George Russell. MacMillian Company.

Bang Herman (1984) Tina. Translated by Paul Christophersen. London: The Athlone Press. (initially 1889).

Beckert Jens and Bronk Richard (2018) Introduction. In Beckert J and Bronk R (eds), Uncertain Futures.Oxford: Oxford University Press.

Bentham Jeremy (2010) The Collected Works of Jeremy Bentham. Volume 11. Michael Quinn eds. Oxford: Oxford University Press.

Berezin, Mabel (2009) Illiberal Politics in Neoliberal Times. (Cambridge: Cambridge University Press).

Berman Sheri (1998) The Social Democratic Moment. Cambridge: Harvard University Press.

Block Fred and Somers Margaret (2014) The Power of Market Fundamentalism. Cambridge: Harvard University Press.

Bonoli Giuliano (1997) Classifying Welfare States. Journal of Social Policy 26 (3), 351-372.

Bokkenheuser, Knut (1903) Drejers Klub. Gyldendalske Boghandels Forlag.

Brantlinger, Patrick (1998) The Reading Lesson. Bloomington: Indiana University Press.

Busemeyer Marius, Garritzmann Julian, and Neimanns Erik (2020) A loud but noisy signal?

PublicOpinion and Education Reform in Western Europe. Cambridge: Cambridge University Press.

Carney Bethan (2017) Social-Problem Novel. Oxford Biographies. http://www.oxfordbibliographies.com/view/document/obo-9780199799558/obo9780199799558-0011.xml.

Castel Robert (1995) Les Métamorphoses de La Question Sociale. Paris: Fayard.

Castles Francis G. (ed.) (1993) Families of Nations. Aldershot: Dartmouth.

Chandler, James K (1980) Wordsworth and Burke. ELH 47 (4 Winter): 741-771.

Chevalier Tom (2016) Varieties of Youth Welfare Citizenship. Journal of European Social Policy (26), 3-19. 
Childers Joseph W. (2001) "Industrial Culture and the Victorian Novel." In Deirdre David (ed), The Cambridge Companion to the Victorian Novel. Cambridge, UK: Cambridge University Press.

Coleridge, Samuel Taylor (1956) Collected Letters of Samuel Taylor Coleridge. III. Earl Griggs eds. Oxford: Clarendon Press.

Cox Robert Henri (1992) From Safety Net to Trampoline. Governance 11, 397-414.

Cusack Thomas, Iversen Torben, and Soskice David (2007) Econmic Interests and the Origins of Electoral Institutions. American Political Science Review 101, 373-391.

Daniel Christine, and Tuchszirer Carole (1999) L'État face aux chômeurs. L'indemnisation du chômage de 1884 à nos jours. Paris : Flammarion.

Den Store Danske Gyldendal. Danmark -- Social Sikring. http://denstoredanske.dk/Samfund,_jura_og_politik/Samfund/Sociale_forhold_i_verden/Danmar $\underline{\mathrm{k} \text { ___social_sikring }}$

Dessertine Dominique and Faure Olivier (1992) Assistance Traditionnelle, Assistance Nouvelle. Gueslin André and Guillaume Pierre (eds), De La Charité Médiévale à La Sécurité Sociale. Paris: Editions Ouvrières, pp.139-52.

Doheny, John (1991) Bureaucracy and the Education of the Poor in Nineteenth Century Britain. British Journal of Educational Studies XXXIX (3 August): 325-339.

Esping-Andersen Gosta (1990) The Three Worlds of Welfare Capitalism. Princeton: Princeton University Press.

Estevez-Abe Margarita, Iversen Torben, and Soskice David (2001) Social Protection and the Formation of Skills. In Hall Peter and Soskice David (eds), Varieties of Capitalism,. Oxford University Press, pp.145-83.

Falleti Tulia G, Lynch Julia (2009) Context and Causal Mechanisms in Political Analysis. Comparative Political Studies, 42(9), 1143-1166.

Fessenbecker, Patrick (2016) A Washy Draught and a Husky Morsel. Victorians: A Journal of Culture and Literature 130.2 (Fall).

Flora Peter, and Heidenheimer Arnold J (eds) (1981) The Development of Welfare States in Europe and America. Transaction Publishers.

Foerster Robert F (1912) The British National Insurance Act. The Quarterly Journal of Economics 26, 275-312.

Frederiksen, Kurt L (2020) Holger Drachmann: Vi vil fred her til lands. En biografi. Copenhagen: Gyldendal.

Geremek Bronislaw (1997) La potence ou la pitié. Paris: Gallimard. 
Gilbert Bentley (1976) David Lloyd George: Land, The Budget, and Social Reform. The American Historical Review 81, 1058-1066

Gough, Ian, et al. (1997) Social Assistance in OECD Countries. Journal of European Social Policy 7(1), 17-43.

Gourevitch, Peter (1986) Politics in Hard Times. Ithaca: Cornell University Press.

Griswold Wendy (1987) A Methodological Framework for the Sociology of Culture. Sociology Methodology 17, 1-35.

Grundtvig (1904-09) Udvalgte Skrifter. Copenhagen: Gyldendalske Boghandel.

Gutton Jean-Pierre (1974) La Société et Les Pauvres En Europe, XVIe-XVIIIe Siècles. Paris: Presses universitaires de France.

Guy Josephine (1996) The Victorian Social-Problem Novel. London UK: MacMillan Press.

Hall Peter A (1993) Policy Paradigms, Social Learning, and the State. Comparative politics 25(3), 275-96.

Hanson, Kathryn Shailer (1993) Adam Oehlenschlager's 'Erik og Roller' and Danish Romanticism. Scandinavian Studies 65 (2 Spring): 180-195.

Harris Jose (1992) Political Thought and the Welfare State 1870-1940. Past \& Present 135, 116141.

Hatzfeld Henri (1971) Du Paupérisme à La Sécurité Sociale. Essai Sur Les Origines de La Sécurité Sociale En France. 1850-1940. Paris: Armand Colin.

Henrichsen, Erik (1911) Christen Berg. København: Gads Forlag.

Holberg Ludvig (1971) Værker i tolv Bind. Billeskov Jansen og Lindhardt og Ringhof Forlag $A / S$.

Holberg Ludvig (1845) Niels Klim's Journey Under the Ground. Trans. By John Gierlow. Boston: Saxton, Peirce \& Co. 1845. Original Niels Klims Underjordiske Rejse. 1741.

Huber Evelyne, and Stephens John D (2001) Development and Crisis of the Welfare State. Chicago: University of Chicago Press.

Hudemann-Simon Calixte (1997) L'Etat et Les Pauvres. Jan Thorbecke Verlag Sigmaringen.

Hughes, James (1903) Dickens as an Educator. New York: Appleton and Company.

Huntington Samuel (1996) The Clash of Civilizations and the Remaking of the World Order. New York: Simon \& Schuster. 
Hvidt, Kristian (2017) Edvard Brandes, Portrat af en radikal blaksprutte. Copenhagen: Gyldendal.

Iversen Torben and Stephens John. (2008) Partisan Politics, the Welfare State, and Three Worlds of Human Capital Formation. Comparative Political Studies 41 (4/5), 600-637.

Jameson Frederic (1981) The Political Unconscious: Narrative as a Socially Symbolic Act. Cornell University Press.

Kahl Sigrun (2005) The Religious Roots of Modern Poverty Policy. European Journalf of Sociology 46(1), 91-126.

Keen Paul (1999) The Crisis of Literature in the 1790s. Cambridge: Cambridge University Press.

King Desmond (1995) Actively Seeking Work? Chicago: University of Chicago Press.

Kipling, Rudyard (1928) A Book of Words. London: Charles Scribner's Sons.

Knight, William (1907) Letters of the Wordsworth Family. Boston: Ginn\&Co.

Korpi, Walter (1974) Conflict, Power and Relative Deprivation. American Political Science Review 68 (4 December): 1569-1578.

Korpi Walter and Palme Joakim (1998) The Paradox of Redistribution and Strategies of Equality: Welfare State Institutions, Inequality, and Poverty in the Western Countries. American Sociological Review 63(5), 661.

Kuhn, John (1971) Some Notes on Matthew Arnold's Thought on Education and Culture. Notre Dame English Journal 7 (1 Fall): 52-66.

Lamont, Michelle and Thevenot Laurent (2000) Introduction. In Lamont and Thévenot (eds) Rethinking Comparative Cultural Sociology. Cambridge: Cambridge University Press, pp.1-22.

Lipset Seymour M, and Rokkan Stein (1967) Party Systems and Voter Alignments. Free Press.

Lyons Martyn (1987) Le triomphe du livre. Paris : Editions du Cercle de la Librairie.

Mahoney James and Goerz Gary (2006) A Tale of Two Cultures. Constrasting Quantitative and Qualitative Research. Political Analysis, 14(3), 227-249.

Malthus, Thomas R (1809) An Essay on the Principle of Population Vol. 1. Washington City: Roger Chew Wrightman.

Manow Philip and Palier Bruno (2009) A Conservative Welfare State Regime without Christian Democracy? In Van Kersbergen Kees and Manow Philip (eds). Religion, Class Coalitions, and Welfare States, Cambridge: Cambridge University Press.

Martin, Cathie Jo and Swank Duane (2012) The Political Construction of Business Interests. Cambridge: Cambridge University Press. 
Martin, Cathie Jo (2018) Imagine All the People. World Politics 70 (3): 398-442.

McDonagh Eileen (2015) The Monarchial Origins of the Welfare State. Perspectives on Politics. 13 (4 Dec), 992-1016.

Macfarlane Alan (1973) The Origins of English Individualism. New York: Cambridge University Press.

McNamara Kathleen (2015) The Politics of Everyday Europe. Oxford: Oxford University Press.

Millgate, Michael (2004) Thomas Hardy: A Biography Revisited. New York, N.Y.:

Oxford University Press.

Milner Andrew (2005) Literature, Culture, and Society. London and New York: Routledge.

Morel Nathalie, Palier Bruno and Palme Joakim (2012) Towards a Social Investment Welfare State? Ideas, Policies, and Challenges. Bristol: The Policy Press.

Munck, Thomas (1998) Absolute Monarchy in Later Eighteenth-Century Denmark. The Historical Journal 41 (1 Mar): 201-224.

Palier, Bruno (ed) (2010) A Long Goodbye to Bismarck? The Politics of Welfare Reform in Continental Europe. Amsterdam: Amsterdam University Press.

Petersen Jorn Henrik, Petersen Klaus, and Christiansen Niels Finn (2010) Dansk Velfardshistorie: Frem mod socialhjalpsstaten. Bind 1. Perioden 1536-1898.

Pierson Christopher (1998) Beyond the Welfare State. Pennsylvania State University Press.

Plesner, Knud Frederek (1930) Jens Schelderup Sneedorff. Copenhagen: Levin \&Munksgaard.

Poovey Mary (1995) Making A Social Body. Chicago: University of Chicago Press.

Quadagno Jill (1988) The Transformation of Old Age Security. University of Chicago Press.

Radé Christophe (2015) Emile Zola et Le Roman Ouvrier. Droit Social (4), 313-25.

Renard Didier (1986) L'assistance en France au 19e Siècle. International Review of Community Development 16, 9-25.

Rimlinger Gaston (1971) Welfare policy and industrialization in Europe, America, and Russia. New York: John Wiley and Sons Inc.

Sassier Philippe (1990) Du Bon Usage des Pauvres. Paris: Fayard.

Schmidt Vivien A (2008) Discursive Institutionalism. Annual Review of Political Science 11(1), $303-26$.

Schwartz Robert M (1988) Policing the Poor in Eighteenth-Century France. Chapel Hill: The University of North Carolina Press. 
Schwarz, Daniel (1983) The Importance of Ian Watt's 'The Rise of the Novel. The Journal of Narrative Technique 13 (2 Spring): 59-73.

Shaw, Bernard (2017) Pygmalion. Digital edition.

Shepard Walter James (1912) The British National Insurance Act. The American Political Science Review 6 (2 May), 229-234.

Skovgaard-Petersen, Vagn (1976) Dannelse og Demokrati. Copenhagen; Gyldendals pædagoiske bibliotek.

Steinlight, Emily (2018) Populating the Novel. Ithaca: Cornell University Press.

Sundberg, Kerstin (2004) Serfdom and literacy in northern manorial worlds. In Modernization and Tradition. II. Lund, Sweden: Nordic Academic Press. 132-52.

Svallfors Stefan (1997) Worlds of Welfare and Attitudes to Redistribution. European Sociological Review 13 (3 Dec), 283-304.

Swidler Ann (1986) Culture in Action. American Sociological Review 51 (2 April), 273-86.

Trampusch Christine, Palier Bruno (2016) Between X and Y: how process tracing contributes to opening the black box of causality. New Political Economy, 21(5), 437-454.

Trimmer, Sarah (1801) Economy of Charity. London: Johnson and Rivington.

Van Kersbergen Kees and Manow Philip (eds) (2009) Religion, Class Coalitions, and Welfare States. Cambridge: Cambridge University Press.

Van Oorschot, Wim, Opielka Michael, and Pfau-Effinger Birgit (eds) (2008) Culture and Welfare State. Cheltenham: Edward Elgar Publishing.

Webb Sidney (1909) Problem of Unemployment in United Kingdom. The Annals of the American Academy of Political and Social Science 33 (2 Mar), 196-215.

Weir, Margaret, Orloff Ann Shola and Skocpol Theda (eds) (1988) The Politics of Social Policy in the United States. Chicago.

Wessel Hansen, Peter W (2008) Den strafværdige gavmildhed. Fortid og Nutid (September): 173-197.

Wiborg Susanne (2000) Political and Cultural Nationalism in Education. Comparative Education 36 (2 May, Special Number (22), 235-243.

Wilensky Harold L (1975) The Welfare State and Equality. Berkeley: University of California Press.

Williams, Raymond (1958) Culture and Society, 1780-1950. New York, N.Y: Columbia University Press. 
Wollstonecraft Mary (1798) Maria or the Wrongs of Woman. A Public Domain Book. 


\section{FIGURE 1}

\section{CAUSAL LOGIC OF ARGUMENT}

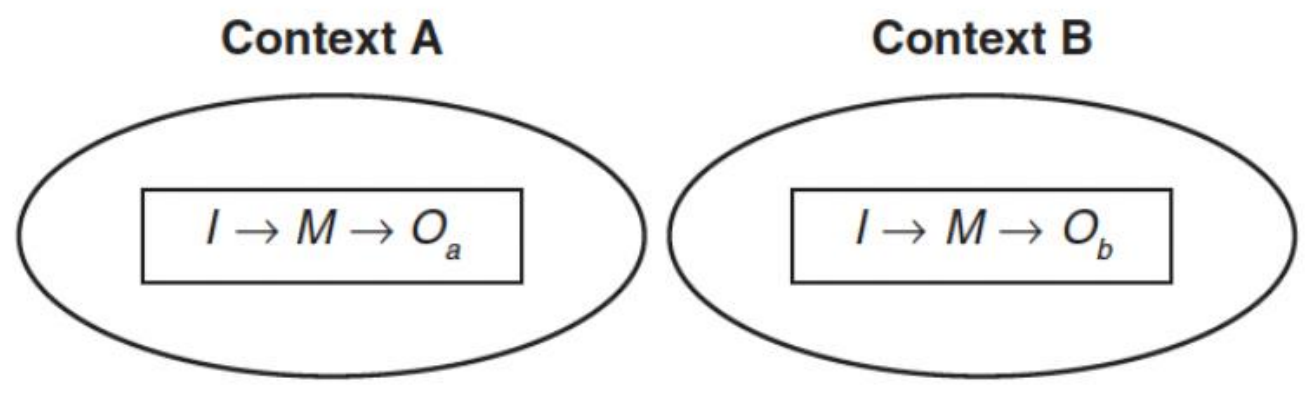

Note: $I=$ inputs; $M=$ mechanisms; $O=$ outputs

Source: Falleti and Lynch 2009 


\section{FIGURE TWO}

\section{FREQUENCIES OF ALL POVERTY WORDS}

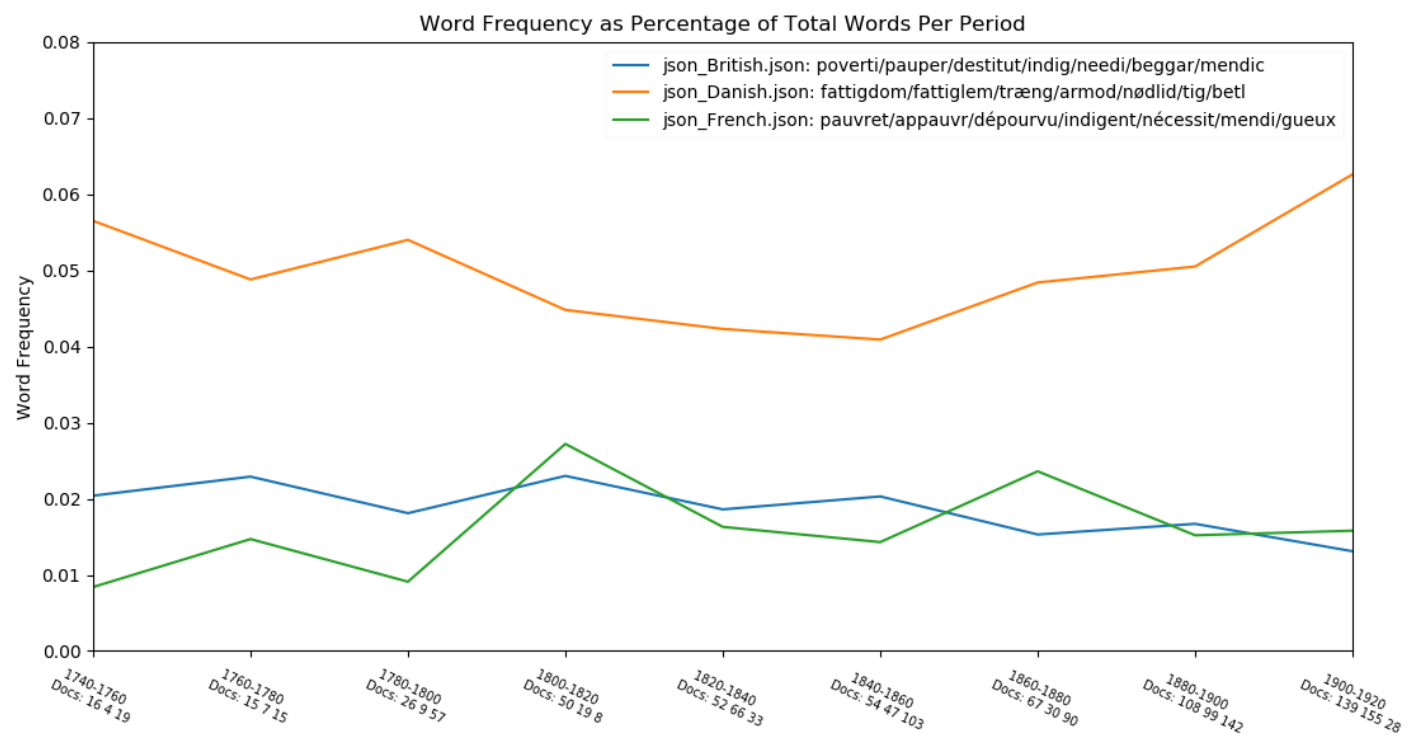

Words include poverty, pauper, destitute, indigent, beggar, mendicant 


\section{FIGURE THREE}

\section{FREQUENCIES OF SKILLS WORDS (WITHIN POVERTY SNIPPETS)}

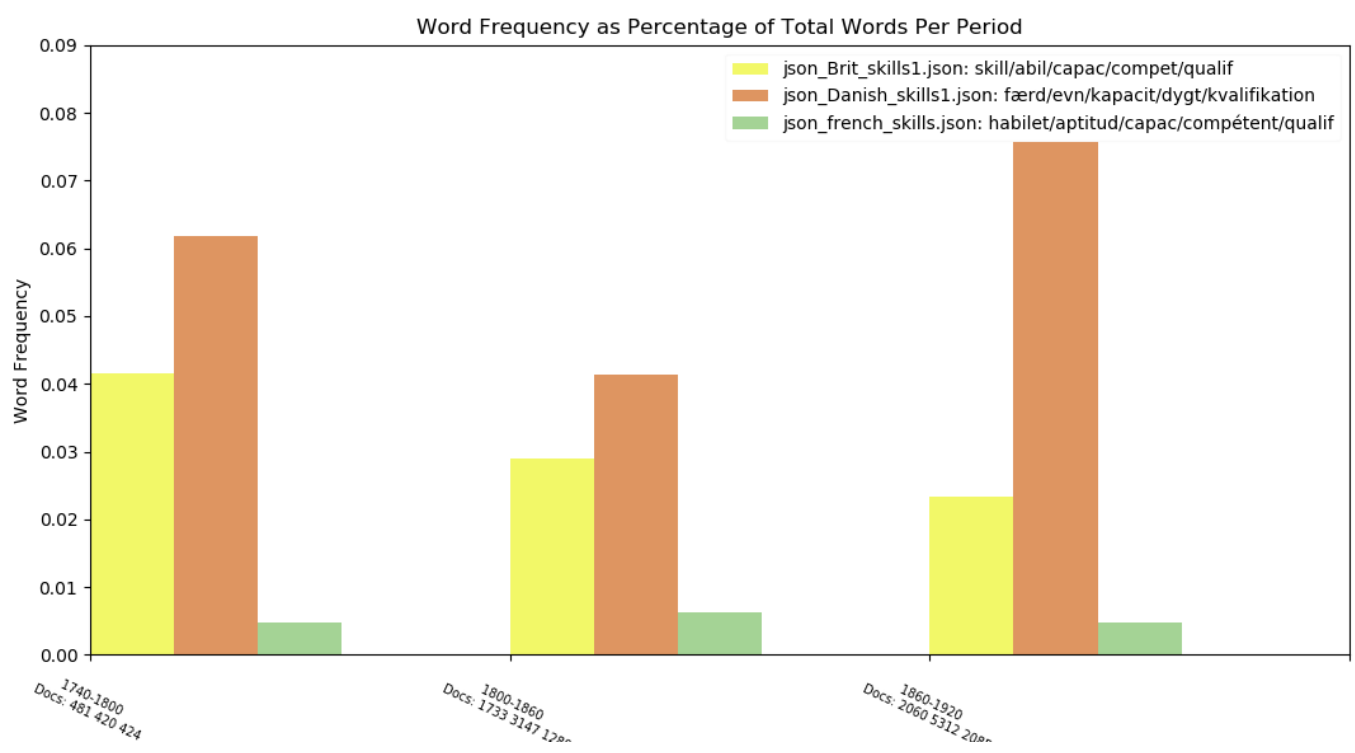

Words include skill, ability, capacity, competency, qualification 


\section{FIGURE FOUR}

\section{FREQUENCIES OF CHARITY WORDS (WITHIN POVERTY SNIPPETS)}

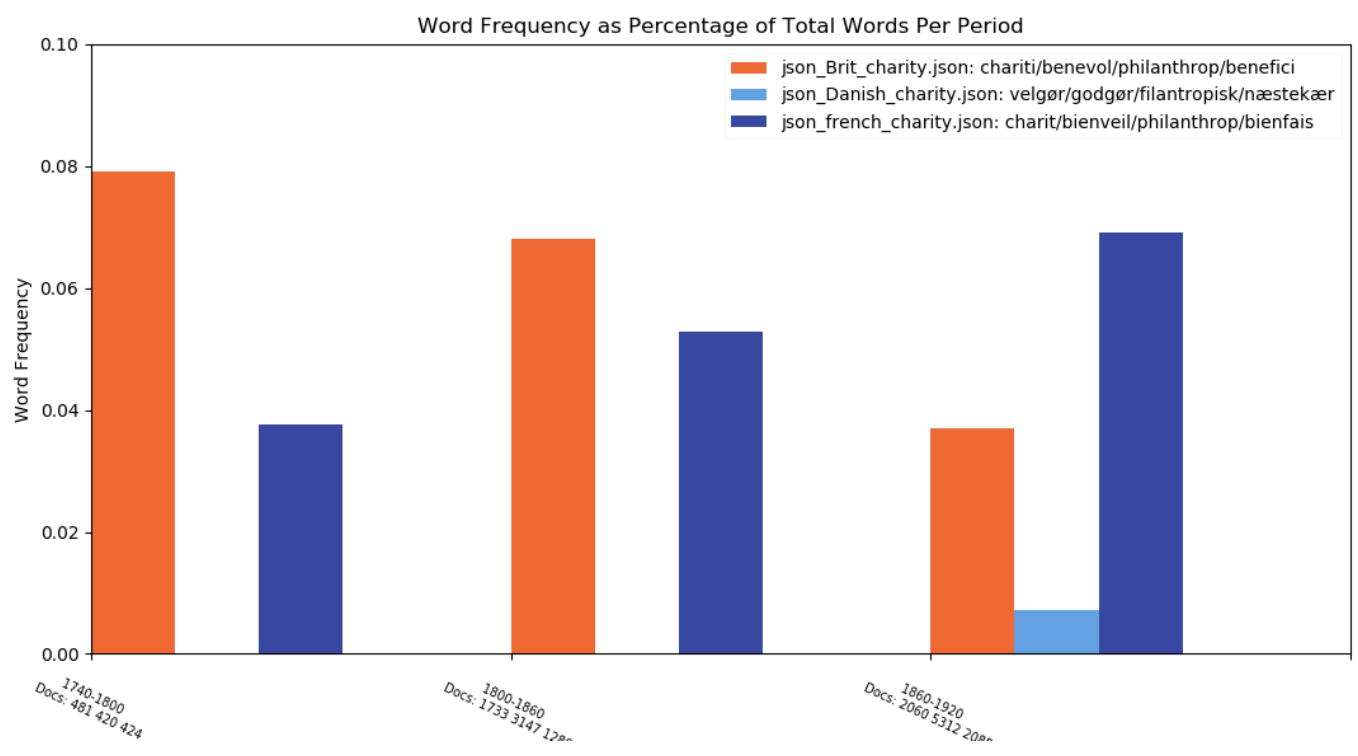

Words include charity, benevolence, philanthropic, and beneficence 


\section{FIGURE FIVE}

\section{FREQUENCIES OF SOCIETY WORDS}

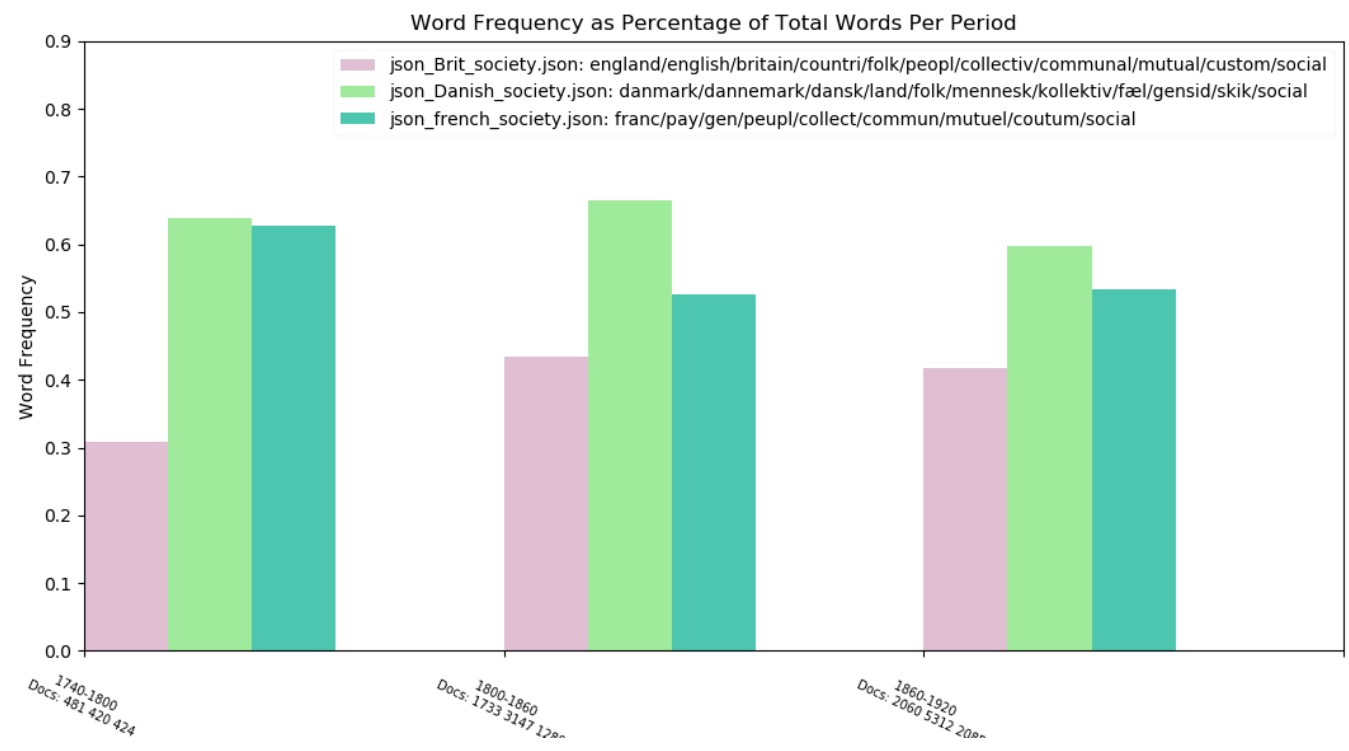

Words include England, English, Britain, country, folk, people, collective, communal, mutual, custom, social 


\section{FIGURE SIX}

\section{FREQUENCIES OF INDIVIDUALISM WORDS (WITHIN POVERTY SNIPPETS)}

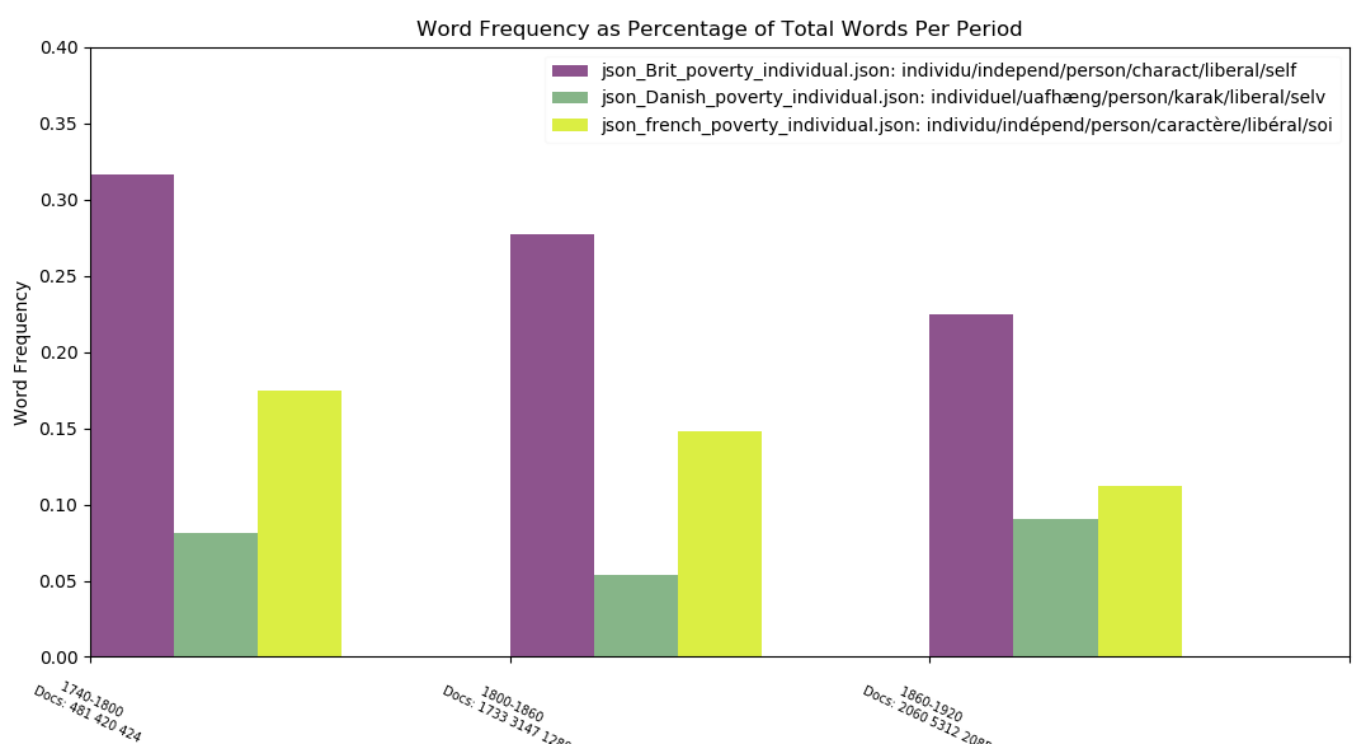

Words include individual, independent, person, character, liberal, self 


\section{FIGURE SEVEN}

\section{FREQUENCIES OF FAMILY WORDS (WITHIN POVERTY SNIPPETS)}

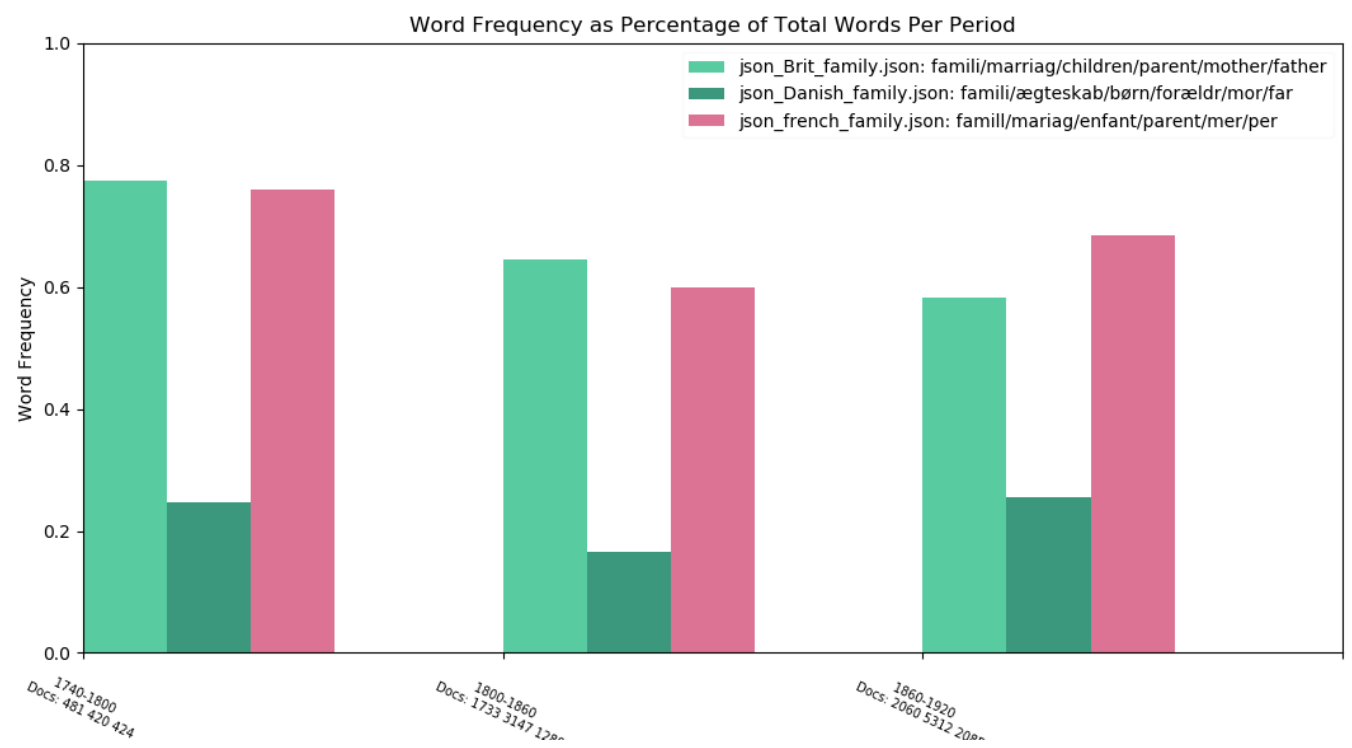

Words include family, marriage, children, parent, mother, father 


\section{FIGURE EIGHT}

\section{FREQUENCIES OF GOVERNMENT WORDS (WITHIN POVERTY SNIPPETS)}

\section{Word Frequency as Percentage of Total Words Per Period}

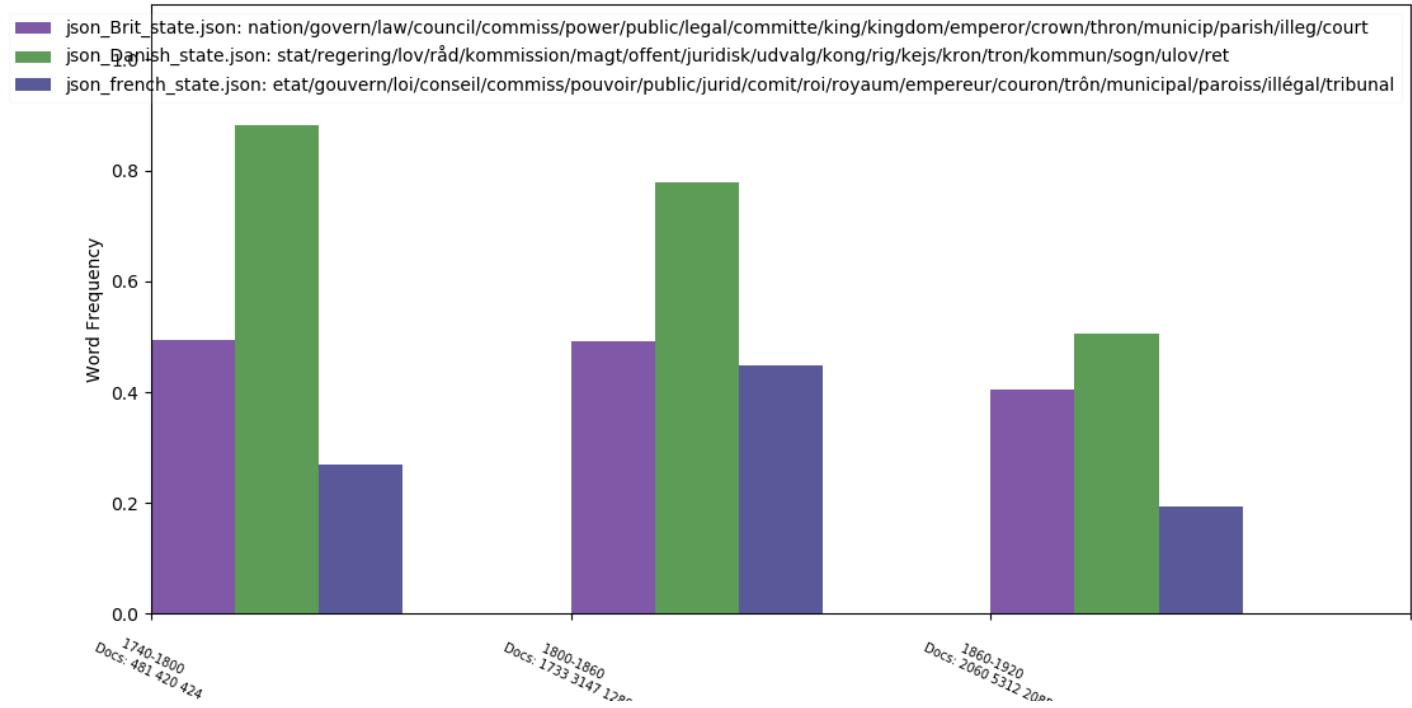

Words include nation, government, law, council, commission, power, public, legal, committee, king, kingdom, emperor, crown, throne, municipal, parish, illegal, court 
FIGURE NINE

FREQUENCIES OF RELIGION WORDS (WITHIN POVERTY SNIPPETS)

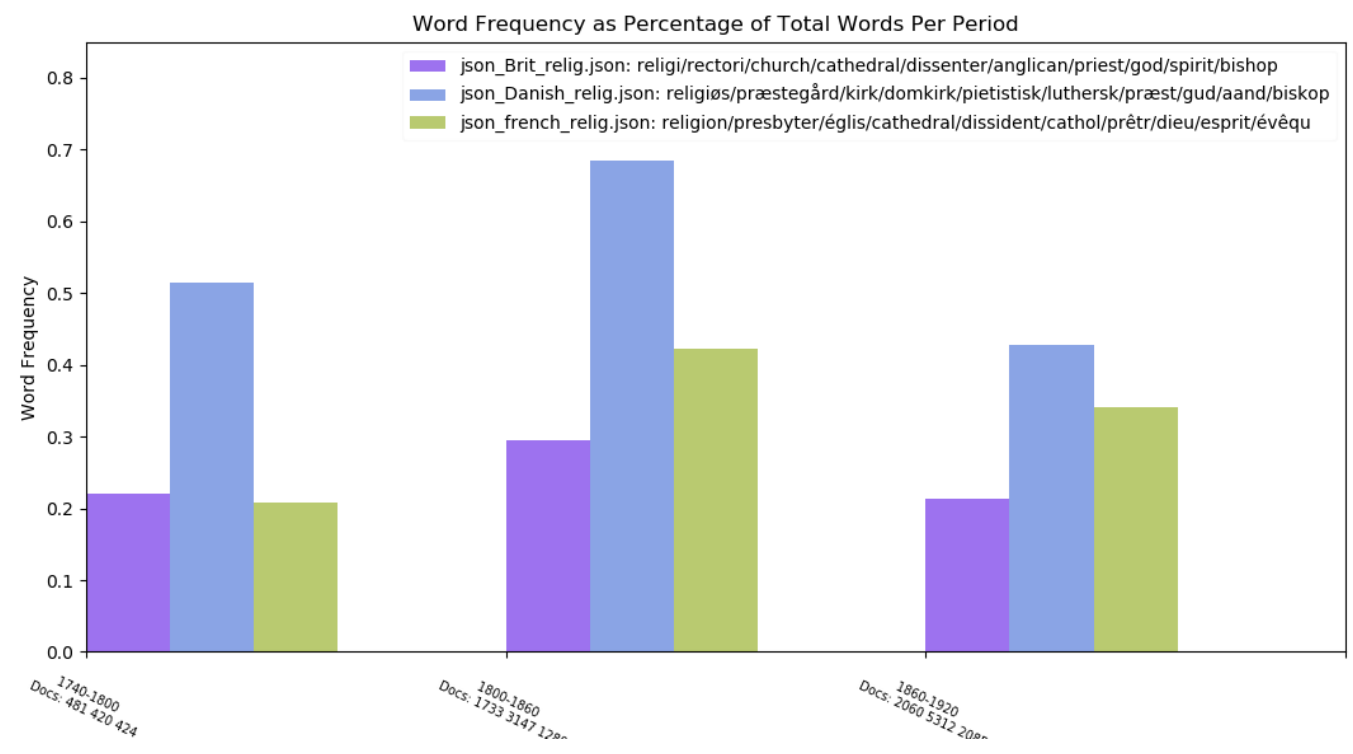

Words include religious, rectory, church, cathedral, dissenter, Anglican, priest, God, spirit, bishop 


\section{APPENDIX}

TABLE ONE

INSTITUTIONAL DESIGN OF WELFARE REGIMES AT THE BEGINNING OF THE TWENTIETH-CENTURY

\begin{tabular}{|l|l|l|l|}
\hline & Denmark & Britain & France \\
\hline Welfare regime & Social Democratic & Liberal & Christian-Democratic \\
\hline $\begin{array}{l}\text { Agency: } \\
\text { State, Market and } \\
\text { non-state actors }\end{array}$ & State & State and market & $\begin{array}{l}\text { Historically church } \\
\text { Unions/family }\end{array}$ \\
\hline $\begin{array}{l}\text { Beneficiaries: } \\
\text { Universal social } \\
\text { assistance and social } \\
\text { insurance programs }\end{array}$ & $\begin{array}{l}\text { Large universal } \\
\text { programs. } \\
\text { Large Ghent system }\end{array}$ & $\begin{array}{l}\text { Small universal } \\
\text { programs. } \\
\text { Small, compulsory } \\
\text { unemployment } \\
\text { insurance }\end{array}$ & $\begin{array}{l}\text { Small universal } \\
\text { programs. } \\
\text { Restrictive Ghent } \\
\text { system }\end{array}$ \\
\hline $\begin{array}{l}\text { Residual social } \\
\text { assistance programs }\end{array}$ & $\begin{array}{l}\text { Small with strong } \\
\text { activation }\end{array}$ & $\begin{array}{l}\text { Greater reliance on } \\
\text { passive, residual } \\
\text { benefits }\end{array}$ & Fragmented programs \\
\hline
\end{tabular}


TABLE TWO

WORDS ASSOCIATED WITH EACH POLICY DIMENSION OF DIVERSE WELFARE REGIMES

\begin{tabular}{|l|l|l|}
\hline & $\begin{array}{l}\text { Agent: Government } \\
\text { Tools: Regulation }\end{array}$ & $\begin{array}{l}\text { Agent: } \text { Church, worker funds, or } \\
\text { other social insurance }\end{array}$ \\
\hline $\begin{array}{l}\text { Beneficiary: Society } \\
\text { Instruments: } \\
\text { Social investments in } \\
\text { skills } \\
\text { High spending } \\
\text { Universal programs }\end{array}$ & $\begin{array}{l}\text { Social Democratic model } \\
\text { Denmark } \\
\text { Expected high word } \\
\text { frequencies: } \\
\text { Government, } \\
\text { society, } \\
\text { skills/social investments }\end{array}$ & \\
\hline $\begin{array}{l}\text { Beneficiary: Individuals, } \\
\text { feelings, } \text { children, families } \\
\text { Instruments: } \\
\begin{array}{l}\text { Low spending } \\
\text { means-tested programs } \\
\text { Charity }\end{array}\end{array}$ & $\begin{array}{l}\text { Liberal model } \\
\text { Britain } \\
\text { Expected high word freq: } \\
\text { Government, } \\
\text { individual, feelings, } \\
\text { charity, families }\end{array}$ & $\begin{array}{l}\text { Christian Democratic Model } \\
\text { Expected high word frequencies: } \\
\text { Church } \\
\text { individual, feelings, } \\
\text { Charity, families }\end{array}$ \\
\hline
\end{tabular}


TABLE THREE

HISTORICAL DIFFERENCES IN SOCIAL POLICY

\begin{tabular}{|c|c|c|c|}
\hline & Britain & Denmark & France \\
\hline $\begin{array}{l}\text { To } \\
\text { mid } \\
1700 \mathrm{~s}\end{array}$ & $\begin{array}{l}\text { Poor Law of } 1536 \\
\text { parish distributes aid } \\
\text { Poor Law of } 1601 \\
\text { sets up system, Parish, poor tax } \\
\text { worthy v. unworthy poor } \\
\text { govn aid to worthy poor } \\
\text { Abolishes begging } \\
\text { Settlement Act restricts } \\
\text { movement between parishes }\end{array}$ & $\begin{array}{l}\text { Poor law of } \mathbf{1 5 5 2}, \\
\text { Parish aid, public works } \\
\text { First Care Act of } \mathbf{1 7 0 8} \\
\text { Sets up system, parish, poor tax } \\
\text { worthy v. unworthy poor } \\
\text { govn aid to worthy poor } \\
\text { Abolishes begging } \\
\text { alms-givers also fined }\end{array}$ & $\begin{array}{l}\text { No poor laws in 1500s } \\
\text { Church support, hospitals } \\
\mathbf{1 7 2 4} \text { Act } \\
\text { No formal system, some } \\
\text { state funds for hospitals } \\
\text { Outdoor relief for worthy } \\
\text { poor by church } \\
\text { Restricts begging }\end{array}$ \\
\hline $\begin{array}{l}\text { Late } \\
1700 \mathrm{~s}\end{array}$ & $\begin{array}{l}\text { Relief of Poor Law in } \mathbf{1 7 8 2} \\
\text { Outdoor relief for able poor } \\
\text { Poor houses for others }\end{array}$ & $\begin{array}{l}\text { Poverty Commission } \mathbf{1 7 8 7} \\
\text { outdoor relief for able poor } \\
\text { Poor houses for others } \\
\text { Duty of local govn to provide } \\
\text { work to job seekers } \\
\text { Became } 1802 \text { poverty } \\
\text { regulations }\end{array}$ & $\begin{array}{l}\text { Efforts byTurgot } \\
\text { Commission in } 1774 \text { and } \\
\text { Comité de mendicité } 1790 \\
\text { to increase state role } \\
\text { Outdoor relief for able } \\
\text { by } 1815 \text {, return to private } \\
\text { charity \& no public support }\end{array}$ \\
\hline $\begin{array}{l}\text { Mid } \\
1800 \mathrm{~s}\end{array}$ & $\begin{array}{l}1834 \text { Poor Law Amendment } \\
\text { Ended outdoor relief } \\
\text { Expanded workhouses \& loss } \\
\text { of civil/political rights } \\
\text { Factory Act of } 1849 \\
\text { Regulated child labor }\end{array}$ & $\begin{array}{l}\text { Constitutional Act } 1849 \\
\text { Ended outdoor relief-but except } \\
\text { Expanded workhouses \& loss of } \\
\text { civil/political rights } \\
\text { But right to social support } \\
\text { 1874 Child Labor Law }\end{array}$ & $\begin{array}{l}1841 \text { child labor regulation } \\
1852 \text { state recognizes } \\
\text { mutualist movement } \\
\text { private charity, church and } \\
\text { family, mutual insurance }\end{array}$ \\
\hline $\begin{array}{l}\text { Circa } \\
1900\end{array}$ & $\begin{array}{l}\text { National Insurance Act } 1911 \\
\text { Health insurance \& first but } \\
\text { very limited compulsory } \\
\text { unemployment insurance }\end{array}$ & $\begin{array}{l}\text { Fattigloven Act } \mathbf{1 8 9 1} \\
\text { Right to basic elderly pensions } \\
\text { Unemployment insurance } \\
\mathbf{1 9 0 7} \text {-- large Ghent voluntary } \\
\text { unemployment insurance; } \\
1913 \text { active labor market policy }\end{array}$ & $\begin{array}{l}\text { Direction de l'assistance } \\
\text { publique } \mathbf{1 8 8 6} \\
1893 \text { public, fragmented } \\
\text { social assistance system } \\
1905 \text { Small private Ghent } \\
\text { voluntary unemployment } \\
\text { insurance }\end{array}$ \\
\hline
\end{tabular}

